ROCZNIK PRZEMYSKI t. 57

HISTORIA z.1 (26) 2021

\author{
KATARZYNA MATYJA (Kraków) \\ orcid.org/0000-0001-9328-9154
}

\title{
DOMINIKANIE TARNOBRZESCY W CZASACH II WOJNY ŚWIATOWEJ W ŚWIETLE KRONIKI ZAKONNEJ. EDYCJA KRYTYCZNA
}

\author{
Abstract \\ The Dominicans in Tarnobrzeg during the Second World War \\ IN THE LIGHT OF A MONASTIC CHRONICLE. A CRITICAL EDITION
}

The aim of the article is to edit an unknown and unused source, i.e. the chronicle of the Tarnobrzeg monastery from 1939-1945. The edition was preceded by a short introduction to the history of the Dominican community in Tarnobrzeg. For the almost entire period of the occupation, Father Fabian Madura was the prior of the monastery in Tarnobrzeg, and in his activities - also for the benefit of the needy - he was characterized by great courage. He acted on many levels: among others he organized aid for the displaced persons from Wielkopolska, or a kitchen for the poorest. He was active in ministry: he founded a choir which performed numerous charity concerts. Other fathers and brothers who lived in the monastery helped him in all the activities.

The source delivers a lot of information about the life of monks in Tarnobrzeg and the history of the city in the war period. The entries from September 1939, when the Nazis invaded the city, are particularly interesting, as well as from the turn of July and August 1944 - at that time Tarnobrzeg was ,liberated" by the Soviet army. As a result of these activities, many buildings - including those belonging to the Dominicans - were seriously damaged, which is also mentioned in the presented source.

Keywords: Dominicans, Tarnobrzeg, monastery, chronicle, World War II, Fabian Madura, Reginald Jadownicki

Słowa kluczowe: dominikanie, Tarnobrzeg, klasztor, kronika, II wojna światowa, Fabian Madura, Reginald Jadownicki.

\section{Wstęp}

Celem artykułu jest edycja dotąd niepublikowanego i nieznanego szerzej tekstu, jakim jest kronika klasztoru tarnobrzeskiego z lat 1939-1945. Podobne źródła - nie 
tylko kroniki, ale również inne dokumenty przechowywane w Archiwum Polskiej Prowincji Dominikanów - często były przedmiotem zainteresowania badaczy. W pierwszej kolejności warto wspomnieć o pracach dwóch historyków, Mariusza Krzysztofińskiego $^{1}$ oraz ks. Józefa Wołczańskiego ${ }^{2}$, które są edycjami krytycznymi kroniki klasztoru dominikańskiego we Lwowie z lat 1939-1943. Pozostając w okresie II wojny, należy wymienić publikację autorstwa Wiktora Szymborskiego, która jest edycją krytyczną wspomnień dwóch dominikanów z września 1939 r. ${ }^{3}$ Inną wartościową publikacją jest tekst o. Marka Miławickiego OP, który dokonał zestawienia kilku kronik proweniencji dominikańskiej z roku 1918. Nie jest to edycja krytyczna, niemniej autor przytacza obszerne fragmenty różnych kronik, ukazując funkcjonowanie poszczególnych wspólnot w $1918 \mathrm{r}^{4}$

Przed zaprezentowaniem samego źródła, zostanie pokrótce przytoczona historia klasztoru tarnobrzeskiego z lat 1939-1945, ponieważ sama kronika nie zawiera wielu informacji, których dostarczają nam inne materiały archiwalne oraz literatura. Bez takiego wprowadzenia obraz życia wspólnoty zakonnej byłby niepełny.

Obecność przedstawicieli Zakonu Kaznodziejskiego w Tarnobrzegu sięga XVII wieku. Przybyli oni na te tereny za sprawą rodu Tarnowskich. W kaplicy zamku w Dzikowie, należącego do wspomnianego rodu, znajdował się obraz Matki Boskiej, który w 1675 roku biskup krakowski Andrzej Trzebicki uznał za cudowny. Tarnowscy, chcąc ożywić procesy miastotwórcze w dotąd słabo rozwijającym się miasteczku, ofiarowali ten wizerunek dominikanom, również sprowadzonym w tym celu. Otrzymali oni w posiadanie kościół i klasztor, ufundowany przez Jana Stanisława Amora Tarnowskiego oraz jego żonę Zofię z Firlejów. Uroczyste przeniesienie obrazu z zamku do kaplicy dotychczasowego kościoła nastąpiło 20 maja 1678 r. ${ }^{5}$ Budowa nowego, murowanego kościoła, według projektów Jana

\footnotetext{
${ }^{1}$ M. Krzysztofiński, Konwent oo. Dominikanów we Lwowie w latach 1939-1943, „Arcana”, 3 (2006), s. 146-164.

${ }^{2}$ J. Wołczański, Relacje o stanie kościoła i klasztoru OO. Dominikanów we Lwowie w latach 1939-1943, [w:] Historia bliższa ludziom. Prace ofiarowane księdzu profesorowi Janowi Kracikowi w 70. rocznicę urodzin, red. E. E. Wróbel, R. Szczurowski, Kraków 2011, s. 429-448.

${ }^{3}$ W. Szymborski, Z więzienia w Tarnopolu przez Lwów, Przemyśl i zielona granicę do Tarnobrzega - krytyczna edycja wspomnień dominikanów o. Romana Madury i br. Jacka Matogi z września 1939 r., „Rocznik Przemyski. Historia”, 53 (2017), z. 1(20), s. 289-325.

${ }^{4}$ M. Miławicki, Wydarzenia roku 1918 widziane zza klasztornego muru. Kroniki klasztorów dominikańskich jako źródto do badań wydarzeń wojennych, [w:] Rok 1918 w Europie Środkowo-Wschodniej, red. D. Grinberg, J. Snopko, G. Zackiewicz, Białystok 2010, s. 642-659.

${ }^{5}$ K. Kuśnierz, Rozwój przestrzenny miasta, [w:] Tarnobrzeg. Dzieje miasta 1593-1939, red. F. Kiryk, Tarnobrzeg 2005, s. 571. Więcej nt. dominikanów w Tarnobrzegu zob. A. Wójcik-Łużycki, Zabytki Tarnobrzega, [w:] Tarnobrzeg. Dzieje miasta 1593-1939, s. 608-626, zwł. 617-619; P. Czepiel, P. Duma, Tarnobrzeg. Kościoły, kaplice, Tarnobrzeg 2015, s. 121-172; A. Wójcik-Łużycki, Tajemnice klasztoru. Z dziejów klasztoru dominikanów w Tarnobrzegu, Tarnobrzeg 2004.
} 
Michała Linka, rozpoczęła się niecałe dwadzieścia lat po przeniesieniu obrazu. Prace trwały kilkadziesiąt lat i ostatecznie zakończyły się w 1782 r. ${ }^{6}$ Corocznie do świątyni przybywali pielgrzymi, szczególnie w dni odpustowe przypadające na Zielone Świątki oraz święto Matki Boskiej Siewnej (8 września) ${ }^{7}$.

Na początku XX wieku dominikanie tarnobrzescy obchodzili dwa ważne wydarzenia. Pierwszym była uroczysta koronacja obrazu Matki Boskiej Dzikowskiej w 1904 r. $^{8}$, a drugim, niedługo później, zakończenie rozbudowy zespołu klasztornego, na którą składało się dobudowanie naw bocznych do kościoła, kruchty oraz wieży ${ }^{9}$. W takich warunkach bracia kaznodzieje niestrudzenie pełnili posługę duszpasterską zarówno wśród okolicznej ludności, jak i przybywających wiernych. Sława cudownego obrazu przyciągała rzesze wiernych, szczególnie po odzyskaniu niepodległości.

W momencie wybuchu II wojny światowej przeorem był o. Teodor Naleśniak ${ }^{10}$, który urząd ten piastował od $1936 \mathrm{r} \cdot{ }^{11}$ Niedługo po rozpoczęciu działań wojennych przełożeni skierowali do Tarnobrzega wybranego na tę funkcję o. Fabiana Madurę, a już po oficjalnym zakończeniu działań wojennych przełożonym tamtejszej wspólnoty został o. Marek Kras ${ }^{12}$. W tym miejscu należy podkreślić, że wyżej wymienieni zakonnicy byli przełożonymi wspólnoty zakonnej, natomiast osobnym urzędem było probostwo tamtejszej parafii ${ }^{13}$. Proboszczem przez cały czas okupacji był o. Reginald Jadownicki.

Stan personalny konwentu tarnobrzeskiego w latach 1939-1945 nie ulegat dużym zmianom. Na początku 1939 do klasztoru było asygnowanych sześciu zakonników, w tym dwóch braci konwersów: ojcowie - Teodor Naleśniak, Jordan Stano, Zygmunt Ogarek, Sebastian Młodecki oraz bracia - Ludwik Wierzbicki oraz Stefan Kruk ${ }^{14}$. W drugiej połowie 1939 r. do Tarnobrzega został skierowany wspomniany już wyżej o. Fabian Madura, a także o. Kasjan Jagiełło oraz o.

\footnotetext{
${ }^{6}$ A. Janas, A. Wójcik, M. Pietras, Tarnobrzeg. Gród Leliwitów, Tarnobrzeg 1999, s. 62.

${ }^{7}$ Por. A. Zielecki, W dobie autonomii (1867-1918), [w:] Tarnobrzeg. Dzieje miasta 1593-1939, S. 289.

${ }^{8}$ D. Komada, Obraz Matki Boskiej Dzikowskiej - jego kopie i naśladownictwa, „Rocznik Tarnobrzeski”, 1(1996), s. 89. W XX w., po kradzieży koron z obrazu, miały miejsce jeszcze dwie koronacje cudownego obrazu w 1933 oraz 1966 r. Zob. ibidem.

${ }^{9}$ K. Kuśnierz, Rozwój przestrzenny miasta, s. 563.

${ }^{10}$ Biogramy dominikanów pracujących w klasztorze tarnobrzeskim są zamieszczone w przypisach do źródła.

${ }^{11}$ Catalogus fratrum ac sororum Provinciae Poloniae Sacri Ordinis Praedicatorum Anno Domini 1937, Leopoli 1937, s. 28 (cyt. dalej: Catalogus).

${ }^{12}$ Catalogus, Cracoviae 1946, s. 16.

${ }^{13}$ Parafia istniała od 1922 roku.

${ }^{14}$ Catalogus, Leopoli 1939, s. 29-30.
} 
Kazimierz Twardy. Ten ostatni spędził tam tylko kilka tygodni i ponownie został przeniesiony. W lutym 1940 r. do wspólnoty tarnobrzeskiej został skierowany o. Anioł Siwek. Kolejna zmiana miała miejsce w listopadzie 1942 r., na miejsce o. Jagiełły do Tarnobrzega został skierowany o. Bronisław Pittner. Taki stan osobowy ojców utrzymywał się do końca wojny. W klasztorze i jednocześnie w parafii tarnobrzeskiej posługę wykonywało dwóch duszpasterzy, który pracowali w omawianym czasie nieprzerwanie. Byli to o. Jordan Stano oraz o. Reginald Jadownicki. Osobami, które również miały długi staż w tej wspólnocie, byli o. Anioł Siwek oraz o. Fabian Madura. Należy jeszcze wspomnieć o obecności braci konwersów. Jak wynika ze źródeł, w klasztorze przez cały czas okupacji pracował brat Stefan Kruk, ponadto dość długo przebywało tam dwóch braci - Jacek Matoga oraz Eliasz Piskorz, natomiast Teodor Wierzbicki, Henryk Ogorzałek i Gordian Dubiel asygnowani byli na krótszy okres ${ }^{15}$. W omawianym czasie przebywali w klasztorze również inni zakonnicy oraz księża, o czym szczegółowo informuje prezentowane źródło. Warto jeszcze wspomnieć, że w klasztorze - poza klauzurą - w pomieszczeniach gospodarczych mieszkali pracownicy klasztorni. Ich liczba zmieniała się w zależności od pory roku oraz sytuacji gospodarczej, związanej z ilością uprawianego pola oraz posiadanych zwierząt. Dla pewnej orientacji można wskazać, że w listopadzie 1941 r. pracowników było 10, w lutym 1942 r. zatrudniano 12 osób, w lipcu 1943 r. - 16 osób, niespełna dwa miesiące później tylko osiem. W większości były to osoby związane z pomocą gospodarską, ale także organista, kucharka czy sekretarz parafii ${ }^{16}$.

Wyżej wymienieni zakonnicy, mimo niesprzyjających warunków zewnętrznych, prowadzili w miarę normalne życie zakonne oraz duszpasterskie. Jak zaznacza historyk zakonu o. Zygmunt Mazur: „konwent w Tarnobrzegu przez cały okres okupacji miał zapewnione warunki do pełnego przestrzegania reguły zakonnej"17. W kościele parafialnym odbywały się msze święte poranne, a od 1944 r. także wieczorne. Duszpasterze dbali, by każdego roku odbywały się rekolekcje roczne. W związku z tym zapraszali różnych kaznodziejów do głoszenia nauk ${ }^{18}$. Przy kościele funkcjonował III Zakon św. Dominika, na czele którego stał przeor o. Fabian Madura, oraz bractwo różańcowe, za które odpowiadał o. Anioł Siwek ${ }^{19}$. Przy parafii działała również Akcja Katolicka, Towarzystwo św. Wincentego á Paulo oraz Stowarzyszenie św. Zyty. Za te grupy był odpowiedzialny proboszcz, o.

${ }^{15}$ APPD, sygn. Tb 100, [brak paginacji]; Catalogus, Cracoviae 1942, s. 20-21; Catalogus, Cracoviae 1946, s. 16-17; Z. Mazur, M. Rudnicka, Dominikanie, [w:] Diecezja Przemyska w latach 1939-1945, t. III: Zakony, red. J. Darus, J. Musiał, Przemyśl 1990, s. 149.

${ }^{16}$ APPD, sygn. Tb 84, passim.

${ }^{17}$ Z. Mazur, M. Rudnicka, Dominikanie, s. 157. Sytuacja ta uległa zmianie pod koniec wojny, gdy Niemcy wycofywali się z miasta, a na ich miejsce wkraczali Sowieci. Wówczas w klasztorze - a dokładniej w jego podziemiach - ukrywała się miejscowa ludność.

${ }^{18}$ APPD, sygn. Tb 100, [brak paginacji]. W jednostce znajdują się szczegółowe rozpiski kazań okolicznościowych oraz programy rocznych rekolekcji.

${ }^{19}$ APPD, sygn. Tb 84, s. 10. 
Jadownicki ${ }^{20}$. Co roku organizowano nabożeństwa 40 -godzinne. Z powodu zakazu prowadzenia procesji religijnych ulicami miasta, odbywały się one wewnątrz świątyni. Jedynym wyjątkiem były procesje po cmentarzu parafialnym w uroczystość Wszystkich Świętych. Dominikanie zgodnie ze swoim charyzmatem gorliwie głosili Słowo Boże, w tym kazania okolicznościowe (majowe oraz październikowe). Należy wspomnieć, że w 1942 r. bracia kaznodzieje otrzymali zakaz głoszenia kazań ze względu na poruszane przez nich treści. Nie wiemy, co dokładnie było przedmiotem nauczania, niemniej musiało to dotyczyć spraw patriotycznych i/lub politycznych, skoro wobec zakonników została zastosowana kara ${ }^{21}$.

Jedną z form duszpasterstwa, jaką praktykowali tarnobrzescy dominikanie, było powołanie do istnienia chóru. Był on prowadzony przez o. Fabiana Madurę i funkcjonował właściwie od początku jego obecności w Tarnobrzegu. Stworzył go wespół z organistą Franciszkiem Falkiewiczem - wysiedleńcem z Rawicza. Pierwsze - jeszcze odrębne - koncerty odbyły się w Boże Narodzenie $1940 \mathrm{r}$. Chórzyści odbywali próby w pomieszczeniach należących do dominikanów. Jak podaje T. Zych: ,uczęszczało na nie przynajmniej raz w tygodniu 60 osób”. Wspólny występ miał miejsce na początku 1941 r. w sali Towarzystwa „Sokół”. Jak wspomina jeden z członków chóru
sala była pełna, mieszkańcy Tarnobrzega przyszli na koncert ubrani odświętnie, głównie na czarno. Wyglądało to jak wielka manifestacja. Na podium Sali stały 2 fortepiany, na których akompaniowali zawodowi muzycy, jeden z Rawicza, a drugi z tarnobrzeżanin Stanisław Czarny. Program składał się z pieśni i muzyki religijnej. Wykonywaliśmy m.in. fragmenty „Pasji” Haendla. Koncert zakończyło odśpiewanie po łacinie Litanii Loretańskiej. Wręcz wstrząsająco zabrzmiało wezwanie „Królowo Korony Polskiej”22.

W grudniu 1944 r. miały miejsce dwa koncerty w sali Państwowego Gimnazjum, z których dochód był przeznaczony na „Gwiazdkę dla Polskiego Żołnierza” oraz na potrzeby Komitetu Opieki Społecznej w Tarnobrzegu ${ }^{23}$. Rok później w marcu odbyły się kolejne dwa koncerty religijne w sali Kasyna w Tarnobrzegu, a dochód z nich został przeznaczony na restaurację kościoła parafialnego w Tarnobrzegu ${ }^{24}$. Ojciec Madura poprzez działalność koncertową zbierał fundusze na odbudowę obiektów sakralnych zniszczonych podczas II wojny światowej. Wysyłał pisma do odpowiednich władz państwowych, w których prosił o zgodę na występ chóru. Z zachowanych źródeł wiemy na przykład, że 14 czerwca 1945 r. poprosił o pozwolenie na koncert w sali Domu Katolickiego w Sandomierzu, zaplanowany na 17 czerwca. Dochód miał być przeznaczony na odnowienie witraży w katedrze

\footnotetext{
${ }^{20}$ Ibidem.

21 T. Zych, Tarnobrzeg pod okupacja niemiecka 1939-1944, s. 174-75.

${ }^{22}$ Cyt. za. T. Zych, Tarnobrzeg pod okupacja niemiecka, s. 98.

${ }^{23}$ APPD, sygn. Tb 149, [brak paginacji], dokument z dn. 10 XII 1944 r.

${ }^{24}$ Ibidem, dokument z dn. 20 III 1945 r.
} 
sandomierskiej ${ }^{25}$. Innym wydarzeniem, na które chciał pozyskać zgodę, był koncert w Stalowej Woli, zaplanowany na 1 lipca 1945 r. Zebrane fundusze miały być przeznaczone na naprawienie zniszczonego kościoła w Tarnobrzegu ${ }^{26}$. W latach 1940-1945 odbyło się kilkanaście koncertów - kolęd oraz innych pieśni religijnych, co ważne, dochód z nich był każdorazowo przeznaczany dla innych. Do $1944 \mathrm{r}$. zbierane były fundusze dla potrzebujących osób - w tym dla żołnierzy, a po $1944 \mathrm{r}$. - na odbudowę i renowację zniszczonych obiektów sakralnych.

Formą pomocy potrzebującym było zorganizowanie kuchni już jesienią $1939 \mathrm{r}$. Korzystali z niej ranni żołnierze polscy oraz wysiedleńcy z Wielkopolski. Zachowała się korespondencja przeora do Kierownictwa Opieki Społecznej w Dębicy z prośbą o dostanie lub umożliwienie zakupu niezbędnych produktów spożywczych oraz opału, by kuchnia mogła funkcjonować. W przypadku działalności, jaką było dożywianie dzieci, zapotrzebowanie rozpisano na 100 obiadów dziennie, zaznaczając jednocześnie, że są to najpotrzebniejsze artykuły „niezbędne do średnio-normalnego odżywiania" ${ }^{27}$. Przedstawiało się ono w sposób następujący: opał - drzewo do gotowania $\left(4 \mathrm{~m}^{2}\right)$, drzewo na podpał $\left(1 \mathrm{~m}^{2}\right)$, węgiel do gotowania (400 kg), węgiel do opalania jadalni dla dzieci $(500 \mathrm{~kg})$; artykuły żywnościowe ziemniaki $(250 \mathrm{~kg})$, kasza jęczmienna (50 kg), kasza jaglana lub makaron $(30 \mathrm{~kg})$, jarzyny świeże (30 kg), mąka na chleb (300 kg); przyprawy - sól (6 kg), cukier $(10 \mathrm{~kg})$, mąka na zasmażki i przyprawy $(15 \mathrm{~kg})$; mięso i thuszcze - wołowina ${ }^{28}$ $(36 \mathrm{~kg})$, thuszcz do omasty ${ }^{29}(30 \mathrm{~kg})^{30}$. Zachowało się jeszcze jedno szczegółowe wyliczenie miesięcznego zapotrzebowania na prowadzenie bezpłatnej kuchni dla ubogich, z tą różnicą, że dla 50 osób. Zapotrzebowanie na opał było takie samo, natomiast na produkty żywnościowe o ok. $30 \%$ mniejsze $^{31}$. Kuchnia najprawdopodobniej funkcjonowała do czasu „wyzwolenia" miasta przez wojska sowieckie ${ }^{32}$. By klasztor mógł podjąć prowadzenie tak szerokiej charytatywnej działalności, sam musiał być niejako „zabezpieczony” pod względem aprowizacyjnym. Zakonnicy posiadali niewielkie gospodarstwo oraz ogród - owocowy oraz warzywny, z których mieli przynajmniej częściowo zapewnione wyżywienie, a także mogli część produktów przekazać na prowadzone kuchnie. Dla przykładu warto przywołać spis z 1942 r., w którym przeor dokonał szczegółowego wyliczenia inwentarza żywego oraz martwego: dwa konie, sześć krów, dwie jałówki, dziewięć świń, trzy owce, dwa barany, szesnaście indyków, osiem gęsi, dwadzieścia dwie kury, dwa koguty

\footnotetext{
${ }^{25}$ Ibidem, dokument z dn. 14 VI 1945 roku.

${ }^{26}$ Ibidem, dokument z dn. 27 VI 1945 roku.

${ }^{27}$ Ibidem.

${ }^{28}$ Po 30 gram na osobę, trzy razy w tygodniu.

${ }^{29}$ Po 10 gram na osobę. W przypadku braku mięsa, racja tłuszczu powinna być zwiększona do

${ }^{30}$ APPD, sygn. Tb 149, [brak paginacji oraz daty].

${ }^{31}$ Ibidem, pismo przeora $\mathrm{z}$ dn. 9 IX $1941 \mathrm{r}$.

${ }^{32}$ Więcej na ten temat zob. Z. Mazur, M. Rudnicka, Dominikanie, s. 162-163.
} $60 \mathrm{~kg}$. 
oraz różnego typu sprzęty gospodarcze, jak wozy, pługi, młockarnie, sieczkarnie, sanie, beczki, łopaty, taczki, piły, wiadra i wiele innych, które umożliwiały odpowiednie zagospodarowanie terenu. W spisie nie zabrakło opisu stanu zasiewów: obsiano pszenicą 3 morgi, żytem 5,5 morgi. Przygotowano pod zasiew: jęczmienia 1,25 morgi, owsa 4,25 morgi, ziemniaków 3,5 morgi, buraków 1,25 morgi ${ }^{33}$.

Klasztor musiał wywiązywać się z obowiązku kontyngentu, np. w sierpniu 1940 r. przełożony otrzymał wezwanie do oddania 800 kop zboża ${ }^{34}$. Nie zabrakło też sytuacji, gdy zakonnicy musieli oddawać zwierzęta gospodarskie, np. 25 października 1941 r. zostali wezwani do oddania jednej krowy ${ }^{35}$, a także wełny ze strzyżenia owiec w maju 1942 r. ${ }^{36}$

Zajmując się badaniem przeszłości wspólnoty tarnobrzeskiej, nie można pominąć szeroko rozumianych prac remontowych w klasztorze oraz kościele. Były one związane zarówno z koniecznymi naprawami, ale także z poprawieniem standardu życia zakonników oraz innych mieszkańców. Te tematy były przedmiotem rozmów na konsyliach klasztornych, na których ojcowie wspólnie podejmowali decyzję, gdzie i w jakim zakresie będą prowadzone prace remontowe. W maju 1940 r. ustalono, że muszą zostać wykonane niezbędne prace naprawcze dachów i rynien w kościele oraz w klasztorze, a także dwóch cel, które były przeznaczone na skład mąki i zboża, oraz żelaznej bramy wjazdowej ${ }^{37}$. Trzy miesiące później podjęto decyzję o odnowieniu chóru - oratorium, gdzie zakonnicy się modlili ${ }^{38}$. W listopadzie zakonnicy uchwalili, że należy zbudować jeden nowy piec kaflowy oraz przestawić kilka już istniejących w klasztorze na pierwszym piętrze. Całość prac została wyceniona na ok. $800 \mathrm{zt}^{39}$. Zaprowadzono instalację elektryczną w obiektach gospodarczych, dalej instalację wodno-kanalizacyjną w klasztorze oraz doprowadzono wodę do pokoi oraz kuchni ${ }^{40}$.

Kolejne duże prace restauracyjne rozpoczęły się pod koniec 1944 r. Prezentowane źródło szczegółowo przybliży stopień uszkodzeń, jakie dotknęły kościół i klasztor. Ojciec Madura jako przeor był bardzo zaangażowany w odnowienie zniszczonych zabudowań. Poza koncertami, z których dochód przeznaczany na ten cel, wielokrotnie zwracał się do różnych instytucji o udzielenie wsparcia w postaci drewna czy blachy, by móc wykonać niezbędne prace ${ }^{41}$. Ponadto dążył do przeprowadzenia zbiórki pieniężnej po domach i sklepach, w tej sprawie

${ }^{33}$ APPD, sygn. Tb 122, [brak paginacji], dokument z dn. 25 XI 1942 r. podpisany przez o. Fabiana Madurę.

${ }^{34}$ APPD, sygn. Tb 149, [brak paginacji], dokument z dn. 29 VIII 1940 r. od Zarządu Miejskiego w Tarnobrzegu.

${ }^{35}$ Ibidem, dokument z dn. 25 IX 1941 r. od Zarządu Miejskiego w Tarnobrzegu.

${ }^{36}$ Ibidem, dokument z dn. $29 \mathrm{~V} 1942 \mathrm{r}$.

${ }^{37}$ APPD, sygn. Tb 84, s. 12.

${ }^{38}$ Ibidem, s. 14.

${ }^{39}$ Ibidem, s. 15.

${ }^{40}$ Z. Mazur, M. Rudnicka, Dominikanie, s. 167.

${ }^{41}$ APPD, sygn. Tb 149, [brak paginacji]. 
również wystosował prośbę do Starostwa Powiatowego. Fundusze miały zbierać oddelegowane do tego osoby z odpowiednią legitymacją Urzędu Parafialnego ${ }^{42}$. Starał się również o uzyskanie pożyczki w wysokości 100000 zł w Banku Gospodarstwa Krajowego ${ }^{43}$.

Kościół i klasztor dominikanów w Tarnobrzegu jawią się jako miejsce, które było ostoją polskości i normalności w tak niepewnym czasie, jakim była okupacja. Było to możliwe za sprawą regularnej pracy duszpasterskiej, udzielania schronienia ludności cywilnej (szczególnie lipiec/sierpień 1944) czy organizowania koncertów. Niewątpliwie ta ostatnia aktywność dawała słuchaczom możliwość chociaż chwilowego oderwania się od otaczającej wszystkich wojennej rzeczywistości. W tym miejscu warto jeszcze wspomnieć o zaangażowaniu mieszkańców klasztoru w tajne nauczanie, a także działalność na rzecz Polski Podziemnej. Prowadzona na szeroką skalę pomoc charytatywna była dobrą okazją do organizowania akcji konspiracyjnych. To właśnie w klasztorze dominikańskim znajdował się punkt kontaktowy Armii Krajowej ${ }^{44}$, ojcowie pomagali także oddziałowi Batalionów Chłopskich ${ }^{45}$. Ważną rolę odegrał wówczas o. Bronisław Pittner, który należał do Zrzeszenia Wolność i Niezawisłość. Był do tego stopnia zaangażowany, że ukrywał w klasztorze archiwum organizacji ${ }^{46}$.

\section{Edycja źródła}

Przedmiotem zamieszczonej poniżej edycji jest fragment kroniki oo. dominikanów z Tarnobrzega, opisujący wydarzenia od września 1939 do grudnia $1945 \mathrm{r}$.

Nie są znane okoliczności powstania źródła. Niewykluczone, że powstało ono po 1945 r. Należy zaznaczyć, że fakty, które podał kronikarz, nie są sprzeczne z innymi źródłami, przedstawiającymi dzieje konwentu tarnobrzeskiego. Możliwe, że autor korzystał ze sporządzonych wcześniej zapisków, stąd zgodność. Najprawdopodobniej autorem kroniki był o. Fabian Madura. Może wskazywać na to fakt, iż zawiera ona wiele szczegółowych, a niekiedy wręcz drobiazgowych wiadomości dotyczących życia zakonników. On, jako ówczesny gospodarz, czuwał nad życiem klasztornym, a także przewodził pracom remontowo-budowlanym, których było dużo, a których opisów nie brakuje w kronice. Jednak zastanawiający, a jednocześnie mogący zaprzeczyć autorstwu o. Madury, jest fakt, że tą samą ręką został spisany również rok 1946, a wówczas o. Madura pracował już w innym konwencie. Z pewnością specjalistyczne badania grafologiczne przyniosłyby odpowiedź na pytanie o autora kroniki dominikanów tarnobrzeskich z omawianego czasu.

\footnotetext{
${ }^{42}$ Ibidem, dokument z dn. 25 VIII $1945 \mathrm{r}$.

${ }^{43}$ Ibidem, dokument z dn. 25 IX $1945 \mathrm{r}$.

${ }^{44}$ W. Szymborski, Ze Lwowa poprzez Włochy, Austrię do odrodzonej Polski-sylwetka i dorobek naukowy o. Romana Fabiana Madury, „Res Gestae. Czasopismo Historyczne”, 4 (2017), s. 102.

${ }^{45}$ Idem, Z więzienia w Tarnopolu, s. 297; Z. Mazur, M. Rudnicka, Dominikanie, s. 165.

${ }^{46}$ Idem, Ze Lwowa poprzez Włochy, Austrię do odrodzonej Polski, s. 297.
} 
W poniższej edycji w większości zachowane zostały zasady omówione w Materiałach do instrukcji wydawniczej dla źródeł do dziejów najnowszych Polski (oprac. S. Kalabiński, F. Tych, Warszawa 1958 [maszynopis powielany]) oraz Edytorstwie źródet historycznych Janusza Tandeckiego i Krzysztofa Kopińskiego (Warszawa 2014, s. 413-447). Za podstawę edycji posłużył rękopis Kronika Konwentu Tarnobrzeg od 1909 r., s. 56-73. Przechowywana jest w Archiwum Polskiej Prowincji Dominikanów w Krakowie, zespół Tarnobrzeg, sygn. Tb 89.

\section{Edycja}

1-go września 1939 roku, w dniu wybuchu wojny z Niemcami w klasztorze pozostawali: o. Jordan $\operatorname{Stano}^{47}$ i o. Reginald Jadownicki ${ }^{48}$. 13-go września wkraczają Niemcy ${ }^{49}$. 17-go września władze niemieckie internowały o. Reginalda Jadownickiego tutejszego proboszcza ${ }^{50}$ jako zakładnika, który wraz z innymi zakładnikami przebywał 5 dni najpierw w budynku gimnazjum ${ }^{51}$, potem w tzw. Zaklikówce ${ }^{52}$, obok szkoły męskiej, a wreszcie w Ubezpieczalni Społecznej. Po pięciu dniach o. Reginald wrócił do klasztoru, gdzie przez dalszych 16 dni był pilnowany jako zakładnik ${ }^{53}$.

${ }^{47}$ Jordan Tomasz Stano - (ur. 5 III 1872 w Siedliskach pod Krakowem, zm. 13 IV 1945 w Tarnobrzegu). Profesję zakonną złożył 3 III 1895 r., a święcenia kapłańskie otrzymał 7 VII 1901 r. Pracował m.in. w Gidlach, Podkamieniu, Tarnobrzegu, przez wiele lat pełnił urząd przeora. Był także gorliwym misjonarzem ludowym. Zob. Ksiega zmartych braci Polskiej Prowincji Zakonu Kaznodziejskiego od 2 lipca tj. od odnowienia Polskiej Prowincji, wydanie do użytku wewnętrznego, Kraków 2020, zapis pod datą 13 kwietnia. (cyt. dalej: Księga zmarlych).

${ }^{48}$ Reginald Andrzej Jadownicki - (ur. 29 XII 1880 w Jadownikach koło Brzeska, zm. 22 VII 1947 w Kluczborku). Profesję zakonną złożył 30 IX 1901 r., a święcenia kapłańskie otrzymał 21 XII 1904 r. Był przeorem klasztoru i proboszczem parafii w Złotym Potoku, subprzeorem i syndykiem konwentu w Krakowie. Pracował także z Gidlach, Tarnobrzegu, Borku Starym i Jarosławiu. Zob. Księga zmartych, zapis pod datą 22 lipca.

${ }^{49}$ Dzień wcześniej, 12 października, Armia „Kraków” oraz Grupa „Sandomierz” otrzymały rozkaz wycofania się za San, co jednoznacznie przesądziło o losach bronionego miasta. W dniu wkroczenia wojsk niemieckich do Tarnobrzega zginął bohaterski obrońca miasta - por. Józef Sarna. Por. T. Zych, Tarnobrzeg pod okupacja niemiecka, s. 28-29.

${ }^{50} \mathrm{~W} 1939$ r. o. Reginald Jadownicki nie był proboszczem tamtejszej parafii. Schematyzm z $1939 \mathrm{r}$. jako proboszcza wymienia o. Teodora Naleśniaka, milczy natomiast o o. Jadownickim. Ten zapis mógł się pojawić jako pomyłka autora kroniki, który wydarzenia wojenne spisywał po czasie. Zob. Catalogus, Cracoviae, 1946, s. 29.

${ }^{51}$ Było to gimnazjum im. hetmana Jana Tarnowskiego w Tarnobrzegu, założone w 1909 r.

${ }^{52}$ Zaklikówka - potoczna nazwa Szkoły Powszechnej powstałej w budynku dworku należącego wcześniej do jednego z braci Zaklików - http://tbc.tarnobrzeg.pl/dlibra/plain-content?id=4485 [dostęp: 22 III 2021].

${ }^{53}$ Zaraz po wkroczeniu Niemców do Tarnobrzega, niejako prewencyjnie wyznaczyli oni grupę kilkunastu zakładników, wśród których znalazł się przeor dominikański oraz m.in. miejscowy rzemieślnik i żydowski adwokat. Przetrzymywano ich do 10 X 1939 r. w budynku starostwa. Była to forma zastraszenia ludności. Należy tu dodać, że takie „listy zakładników” były sporządzane przez cały okres okupacji. Znajdowały się na nich nazwiska mieszkańców miasta, którzy zajmowali się różnymi profesjami, byli z różnych grup społecznych. Takie działanie miało na celu zabezpieczenie przed atakami wymierzonymi w okupanta w ramach tzw. odpowiedzialności zbiorowej. Jak podaje o. Zygmunt Mazur, w 1944 r. na takiej liście znalazł się ówczesny przeor - o. Fabian Madura. Por. T. Zych, Tarnobrzeg pod okupacją niemiecka, s. 46-47; Z. Mazur, M. Rudnicka, Dominikanie, s. 165. 
W połowie września 1939 roku powstała przy klasztorze kuchnia dla biednych i dla uchodźców z terenów zachodnich ${ }^{54}$.

Od 1-go grudnia Żydzi mają obowiązek nosić na lewym ramieniu opaskę białą z niebieską gwiazdą Sy[j]ońską ${ }^{55}$.

16 października wraca do klasztoru o. Teodor Naleśniak ${ }^{56}$ przeor i proboszcz parafii, którego wojna zastała w Warszawie, skąd przez Żółkiew, Lwów, Kraków wrócił do Tarnobrzega.

Od 28 listopada pozostaje w klasztorze o. Kazimierz Twardy ${ }^{57}$ aż do 15 grudnia. Z początkiem grudnia przyjeżdża do Tarnobrzega z asygnatą o. Kasjan Jagiełło ${ }^{58}$.

${ }^{54}$ Z zachowanego materiału wynika, że funkcjonowała ona od 14 X 1939 do 7 VII 1940 r. W głównej mierze korzystali z niej ranni żołnierze, ale także osoby chore, biedne i dotknięte wojną. Szczegółowe dane informują, że między 14 IX a 16 X 1939 r. pomagano 84 osobom poprzez wydawanie śniadań, obiadów, kolacji, ubrań oraz słomy; od 16 X do 20 XII 1939 r. obiady z dwudaniowych obiadów korzystało 120 osób; od 15 I do 7 VII 1940 r. wydano łącznie 23253 obiady. APPD, sygn. Tb 147, [brak paginacji].

${ }^{55}$ Jak podaje Tadeusz Zych, obowiązek noszenia opaski z Gwiazdą Dawida dla osób powyżej 10 roku życia wprowadzono od 23 XI 1939. Por. T. Zych, Tarnobrzeg pod okupacją niemiecka, s. 204.

${ }^{56}$ Teodor Jakub Naleśniak - (ur. 15 VII 1887 w Pawłosiowie koło Jarosławia, zm. 4 XII 1942 w Borku Starym). Profesję zakonną złożył 9 III 1908 r., a święcenia kapłańskie otrzymał 10 VIII 1912 r. w Tarnowie. Rozpoczął studia filozoficzno-teologiczne w studium zakonnym w Krakowie, a następnie został skierowany przez przełożonych na studia w rzymskim Angelicum. Uzyskał tytuł lektora teologii. Wykładał historię dogmatu oraz egzegezę biblijną w studium zakonnym we Lwowie. W latach 1925-1932 był redaktorem dominikańskiego czasopisma „Róża Duchowna”. Ponadto pełnił urząd przeora w Żółkwi (1929-1932), Tarnobrzegu (1936-1939) oraz Borku Starym (1939-1942), był także socjuszem prowincjała. Został zapamiętany jako gorliwy kaznodzieja ludowy oraz dobry rekolekcjonista. Zob. Księga zmartych, zapis pod datą 4 grudnia; Z. Mazur, Naleśniak Teodor Jakub (1887-1942), [w:] Słownik Polskich Teologów Katolickich, t. 6, s. 526-529; C. Wichrowicz, Stownik polskich pisarzy dominikańskich, Kraków 2009, s. 235-338. Słownik nie został on opublikowany w formie drukowanej, dostępny w Bibliotece Kolegium Filozoficzno-Teologicznego Polskiej Prowincji Dominikanów w Krakowie.

${ }^{57}$ Kazimierz Władysław Twardy - (ur. 11 VI 1912 w Grabie koło Krakowa, zm. 18 XII 1942 w Jarosławiu). Uczęszczał do II Państwowego Gimnazjum im. św. Jacka w Krakowie w latach 1923-1928, gdzie zapewne poznał dominikanów. Do zakonu wstąpił w Krakowie, gdzie 31 VIII 1928 r. otrzymał habit. Pierwszą profesję zakonną złożył 1 IX 1929 r., a wieczystą 22 IX 1934 r. Święcenia kapłańskie przyjął 2 V 1937 r. Po wstąpieniu do zakonu uczył się jednocześnie w IV Gimnazjum Państwowym im. Henryka Sienkiewicza w Krakowie, gdzie uzyskał maturę. Po święceniach dostał asygnatę do Jezupola, a po roku do Bohorodczan, gdzie był katechetą, a także prowadził ruch Krucjata Eucharystyczna oraz Katolickie Stowarzyszenie Młodzieży Żeńskiej. Po wybuchu wojny przez kilka miesięcy przebywał w klasztorze krakowskim. Starał się wówczas o przyjęcie na studia wyższe na Wydział Filozoficzny Uniwersytet Jagielloński, co z powodu zamknięcia uczelni przez Niemców było niemożliwe. Otrzymał asygnatę do Tarnobrzega, w 1940 do Borku Starego, a w 1942 do Jarosławia. Zob. APPD, Pp 597/60, O. Twardy Kazimierz Władysław † 18.12. 1942, passim; Ksiega zmarlych, zapis pod datą 18 grudnia; C. Wichrowicz, Stownik polskich pisarzy dominikańskich, s. 552; Catalogus, Leopoli 1939, s. 31; Catalogus, Cracoviae 1942, s. 19; Catalogus, Cracoviae 1946, s. 32.

${ }^{58}$ Kasjan Józef Jagiełło - (ur. 4 VII 1907 w Białobrzegach, zm. 1982 w Szczecinie). Profesję zakonną złożył 25 IX 1928 r., święcenia kapłańskie przyjął 29 VI 1936 r. W 1938 r. pracował w Krakowie, rok później dostał zmianę do Czortkowa, gdzie był katechetą. Od 1940 r. pracował w Tarnobrzegu jako wikariusz. Kolejnym miejscem był Prudnik, gdzie był asygnowany w 1946 r. Wystąpił on z zakonu, po czym został przyjęty do administratury apostolskiej z siedzibą w Gorzowie Wielkopolskim (1947), a po jej przekształceniu był kapłanem archidiecezji szczecińsko-kamieńskiej. Zmarł w Szczecinie w 1982 r. Zob. Schematyzm, Lwów 1938, s. 10; Schematyzm, Lwów 1939, s. 17; Schematyzm, Kraków 1942, s. 20; Schematyzm, Kraków 1946, s. 20; D. Zamiatała, Zrzeszenie Katolików ,Caritas” na Pomorzu Zachodnim w latach siedemdziesiatych XX w., [w:] Dzieje Kościoła katolickiego na Pomorzu Zachodnim, t. 3: 1972-1978, red. M. Siedziako, Z. Stanuch, G. Wejman, Szczecin-Warszawa 2018, s. 305 przyp. 13. 
Obszerniejsze wiadomości z życia klasztoru i Tarnobrzega opisane są i mieszczą się w kronice parafialnej, którą skrzętnie pisał o. Reginald Jadownicki, będąc w tych ostatnich miesiącach 1939 roku w Tarnobrzegu.

Pasterka w tym roku odbyła się rano w dzień Bożego Narodzenia, a nie jak zwykle o północy ze względu [wprowadzenia - dop. KM] godziny policyjnej ${ }^{59}$.

\section{Rok 1940}

W styczniu 1940 roku asygnowani są w klasztorze w Tarnobrzegu następujący ojcowie i bracia:

1/ o. Fabian Madura ${ }^{60}$, przeor

2/ o. Jordan Stano

3/ o. Reginald Jadownicki, proboszcz

4/ o. Kasjan Jagiełło

Z początkiem lutego przyjeżdża z asygnatą o. Anioł Siwek ${ }^{61}$. Z końcem lutego opuszcza Tarnobrzeg o. Teodor Naleśniak.

${ }^{59}$ Godzina policyjna w latach 1939 -1944 nieznacznie się zmieniała. Na początku wojny była od 18.30 do 5.00, następnie została przesunięta od 20.00 do 5.00, a po ostatecznym załamaniu się niemieckiej ofensywy na wschodzie wprowadzono przedział od 17.00 do 5.00 lub do 7.00. Por. T. Zych, Tarnobrzeg pod okupacja niemiecka, s. 113.

${ }^{60}$ Fabian Roman Madura - (ur. 9 IX 1892 we Lwowie, zm. 25 VII 1989 w Warszawie). Do zakonu wstąpił jesienią 1908 r. we Lwowie, po rocznym nowicjacie w Krakowie, złożył tam pierwszą profesję zakonną. Następnie rozpoczął studia filozoficzne we Lwowie. W $1911 \mathrm{r}$. przełożeni skierowali go na studia do Rzymu na Angelicum. 15 IX 1915 r. przyjął święcenia kapłańskie w Sombathely na Węgrzech. Sytuacja wojenna zmusiła go do opuszczenia Włoch, a studia teologiczne ukończył w Wiedniu, po czym rozpoczął studia $\mathrm{z}$ historii na tamtejszym uniwersytecie. W latach 1918-1928 prowadził wykłady w studium zakonnym we Lwowie z logiki, apologetyki i historii Kościoła. Następnie pracował w Krakowie oraz Tarnopolu. Po wkroczeniu Armii Czerwonej, ponad miesiąc przebywał w więzieniu, a następnie dostał się do Tarnobrzegu, gdzie przez całą okupację pełnił urząd przeora. Jednocześnie często podróżował do Warszawy, gdzie kopiował rękopis XV-wiecznych akt kapituł prowincjonalnych polskich dominikanów (został on spalony w 1944). Po wojnie pracował m.in. w Gdańsku (przeor), Jarosławiu (lektor prymariusz), Gidlach (przeor), Warszawie, klasztorze św. Józefa (przeor, lektor prymariusz). W 1957 r. został regensem Studium Generale polskiej prowincji, co skutkowało tym, że uzyskał stopień mistrza teologii. Poza zamiłowaniem historycznym, Madura interesował się również muzyką kościelną. Tworzył i prowadził liczne chóry. Zob. J.A. Spież, Madura Fabian Roman (1982-1989), [w:] Stownik Polskich Teologów Katolickich, t. 8, Warszawa 1995, s. 356-357; C. Wichrowicz, Stownik polskich pisarzy dominikańskich, s. 311-312; W. Szymborski, Z więzienia w Tarnopolu, s. 289-325. Księga zmartych, zapis pod datą 25 lipca.

${ }^{61}$ Anioł Andrzej Siwek - (ur. 10 X 1891 w Trojanowicach koło Krakowa, zm. 27 VI 1964 w Krakowie). Po odbyciu rocznego nowicjatu w Krakowie, 5 V 1910 r. złożył profesję zakonną, a wieczystą 24 VI 1913. Święcenia kapłańskie otrzymał 12 XII 1915 r. W latach 1932-1936 pracował w konwencie krakowskim, pełnił funkcję bibliotekarza, był promotorem bractwa różańcowego oraz dyrektorem Stowarzyszenia bł. Imeldy. W 1936 r. dostał zmianę do Czortkowa, gdzie od 31 VII był subprzeorem oraz proboszczem tamtejszej parafii, a od $5 \mathrm{X}$ magistrem braci konwersów. Ponadto opiekował się Sodalicją Mariańską - grupą żeńską, pełnił funkcję kantora, archiwisty i sekretarza konsylium klasztornego. Od 1940 r. pracował w Tarnobrzegu. W 1946 r. dostał asygnatę do klasztoru Świętej Trójcy w Krakowie, a po roku do Gdańska, gdzie od 1948 r. był mianowany administratorem tamtejszej parafii. Kolejnym miejscem pracy (od 1959 - do śmierci) był Tarnobrzeg. Zob. APPD, Pp 597/114, O. Siwek Aniot Andrzej † 27.06.1964, s. 13,15, 19, 31; C. Wichrowicz, Stownik polskich pisarzy dominikańskich, s. 495; Księga zmarlych, zapis pod datą 27 czerwca; Catalogus, Leopoli 1932, s. 6; Catalogus, Leopoli 1934, s. 7; Catalogus, Leopoli 1936, s. 7; Catalogus, Leopoli 1937, s. 21; Catalogus, Leopoli 1939, s. 17; Catalogus, Cracowiae 1942, s. 20; Catalogus, Cracoviae 1946, s. 17. 
Od marca mieszka w klasztorze ks. prałat Edmund Majkowski ${ }^{62}$ wysiedlony z poznańskiego. W Wielkim Tygodniu i przez święta bawił w klasztorze o. Ex. Prow[incjał] o. Teofil Szczurecki ${ }^{63}$. Następnie przez tydzień z końcem czerwca.

${ }^{62}$ Edmund Majkowski - (ur. 5 XI 1892 w Grodzisku Poznańskim, zm. 5 IV 1951 w Śremie). Szkolę podstawową oraz średnią ukończył w Grodzisku oraz Śremie. Po zdaniu matury wstąpił do seminarium duchownego, gdzie rozpoczął studia z zakresu filozofii i teologii. Święcenia kapłańskie otrzymał 13 II 1916 r. Początkowo został skierowany do pracy w Bninie jako wikariusz, a następnie do Kórnika, gdzie miał okazję pracować w tamtejszej bibliotece. W $1918 \mathrm{r}$. z polecenia rozpoczął pracę jako archiwariusz archidiecezjalny i bibliotekarz Poznańskiego Seminarium Duchownego, niedługo później do jego obowiązków dołączyło kierowanie Muzeum Archidiecezjalnego. Do swoich obowiązków podchodził z dużą odpowiedzialnością i rzetelnością. W 1933 r. wyjechał do Belgii i Holandii, gdzie czynnie angażował się w życie kilku archiwów i bibliotek, organizując odczyty oraz wystawy polskich zbiorów. Po powrocie został zarządcą parafii w Kopanicy - nad samą granicą polsko-niemiecką. Na początku września 1939 r. został aresztowany i wywieziony do obozu pracy w Rzeszy Niemieckiej. Po kilku miesiącach wrócił na ziemie polskie, gdzie osadzony był w Forcie VII w Poznaniu. Na wiosnę 1940 r. wyjechał do Generalnej Guberni, gdzie trafił do klasztoru oo. Dominikanów w Tarnobrzegu. Jego pasja i zamiłowanie, mimo trudnych warunków wojennych, kontynuował poprzez odwiedzanie biblioteki Tarnowskich w sąsiednim Dzikowie. Po zakończeniu działań wojennych powrócił do rodzinnej archidiecezji poznańskiej i objął probostwo w Kórniku. Poprzez zawieruchę wojenną dyplom magistra filozofii uzyskał dopiero 8 V 1945 r., a dwa lata później obronił doktorat na KUL-u z zakresu historii kultury polskiej. Był członkiem PAU, Poznańskiego Towarzystwa Przyjaciół Nauk, Instytutu Słowiańskiego w Pradze. Był autorem kilkudziesięciu prac naukowych, rozpraw, przyczynków, recenzji. Ich przedmiotem były dzieje kościoła w Polsce. Zmarł w Śremie, a pochowany został na cmentarzu w Kórniku. Zob. E. Majkowski, Życiorys własny i spis prac, ,Nasza Przeszłość”, 25 (1966), s. 285-290; T. Zych, Tarnobrzeg pod okupacją niemiecka, s. 67, 172.

${ }^{63}$ Teofil Andrzej Szczurecki - (ur. 3 XI 1889 w Bratkowicach koło Rzeszowa, zm. 27 VI 1975 w Warszawie). Do nowicjatu w Krakowie został przyjęty 20 XII 1905 r., a po roku złożył pierwszą profesję zakonną. Następnie wyjechał do Lwowa, gdzie rozpoczął studia filozoficzno-teologiczne, które od jesieni 1909 r. w Pontificio Instituto Internazionale „Angelicu” w Rzymie. Tam również 10 VIII 1912 r. przyjął święcenia kapłańskie. Po zakończeniu nauki w 1914 r. i uzyskaniu stopnia lektora św. teologii wrócił do Lwowa, gdzie pracował jako wykładowca w Kolegium Filozoficzno-Teologicznym. Prowadził wykłady z psychologii, prawa kanonicznego, kosmologii. W latach 1915-1918 przebywał w Krakowie, gdzie prowadził zajęcia dla nowicjuszy. Po powrocie do Lwowa w 1919 r. został radnym konwentu, a niebawem również redaktorem dominikańskiego miesięcznika „Róża Duchowna”. Od 1921 r. pełnił urząd m.in. syndyka i dyrektora Trzeciego Zakonu św. Dominika w klasztorze w Żółkwi. W 1924 r. powrócił do Lwowa i był rektorem tamtejszego kolegium. 9 V 1924 r. objął funkcję przeora tamtejszego klasztoru. Kapituła prowincjalna dominikanów w Podkamieniu 16 X 1926 r. powierzyła Szczureckiemu pełnienie urzędu prowincjała Prowincji Galicji i Lodomerii św. Jacka. W czasie jego kadencji kapituła generalna dominikanów reaktywowała w 1927 r. Polską Prowincję św. Jacka. Odegrał ważną rolę przy tworzeniu nowego klasztoru w Służewie - wówczas pod Warszawą, gdzie od 1936 r. rozpoczęto budowę. Na przełomie 1933/1934 r. pełnił urząd przeora klasztoru pw. Świętej Trójcy w Krakowie, jednocześnie sprawował funkcję spowiednika dominikanek „na Gródku”. W 1934 r. został wydelegowany do Rzymu na wicepostulatora generalnego ds. beatyfikacji i kanonizacji kandydatów z zakonu dominikańskiego. Rok później wrócił do Polski i we Lwowie objął funkcje wykładowcy etyki oraz spowiednika sióstr urszulanek. W połowie 1934 r. został ponownie przeorem klasztoru w Żółkwi i dyrektorem Trzeciego Zakonu św. Dominika. Po wybuchu II wojny światowej i wkroczeniu do Polski Armii Czerwonej o. Szczurecki opuścił 17 IX 1939 Żółkiew i przedostał się do Krakowa. 12 XII 1939 r. został wybrany subprzeorem tamtejszego konwentu. W przeniesionym tam z podwarszawskiego Służewa Studium Filozoficzno-Teologicznym wykładał filozofię poznania oraz teologię dogmatyczną. 9 VII 1941 r. został spowiednikiem zwyczajnym ss. Dominikanek ,na Gródku”, a niespełna rok później - 23 VI 1942 r. - wikariuszem prowincjała. 15 IX 1942 r. został mu nadany tytuł kaznodziei generalnego. 1 IV 1947 wyjechał do Rzymu, gdzie został asystentem generała zakonu ds. krajów Europy Wschodniej oraz podjął wykłady na Angelicum z teologii moralnej. 29 IX 1971 r. wrócił do Polski i zamieszkał w konwencie św. Józefa w Warszawie. Zob. K. Matyja, Szczurecki Andrzej Teofil (1889-1975), „Słownik Polskich Teologów Katolickich", uzupełnienia do tomów 1-9, red. R. Prejs (w przygotowaniu); C. Wichrowicz, Stownik polskich pisarzy dominikańskich, s. 522; Księga zmarlych, zapis pod datą 27 czerwca. 
Procesja Bożego Ciała z 4 Ewangeliami odbyła się dookoła kościoła, a nie po rynku jak w roku ubiegłym, z powodu zakazu władz niemieckich. Również procesji żałobnej na cmentarzu w dzień Wszystkich Świętych w tym roku nie było.

W tym roku również Pasterki o północy nie było.

\section{Rok 1941}

W styczniu w tym roku w klasztorze pozostają nadal ci sami ojcowie.

30 marca w niedzielę Męki Pańskiej rozpoczął rekolekcje wielkopostne dla parafian o. Ex. Prow[incjał] Lektor o. Teofil Szczurecki i głosił przez cały tydzień aż do Niedzieli Palmowej.

Od 8 lipca aż do 11 września przebywał w klasztorze o. Szymon Ordon ${ }^{64}$. Z początkiem sierpnia bawił też na wakacjach w Tarnobrzegu o. Sadok Kolasiński ${ }^{65}$ nowo wyświęcony kapłan ${ }^{66}$. Z początkiem września był w Tarnobrzegu o. Damian Budnik $^{67}$ przez tydzień.

6-go września za staraniem się i pod kierownictwem o. przeora Fabiana Madury odbył się w sali kina „Casino” koncert religijny, z którego dochód przeznaczono na kuchnię dla ubogich ${ }^{68}$.

${ }^{64}$ Szymon Piotr Ordon - (ur. 21 III 1891 w Mokrzyszowie pod Tarnobrzegiem, zm. 1 VIII 1962 w Gidlach). Wstąpił do Zakonu Kaznodziejskiego w Krakowie, gdzie po rocznym nowicjacie 26 IX 1909 r. złożył pierwszą profesję zakonną. Studia z zakresu filozofii i teologii odbywał w studium zakonnym we Lwowie. Profesję wieczystą złożył 1 XII 1912 r. Święcenia kapłańskie przyjął 12 XII 1915 r. Wybuch II wojny światowej zastał go w Jarosławiu, skąd był zmuszony uciekać do Radawy (pod Jarosław). To przeżycie okazało się być traumatyczne, co odbiło się na załamaniu psychicznym, które towarzyszyło mu do końca życia. Po czasie dostał się do Krakowa, gdzie dostał asygnatę do Gidel. Powrócił do Krakowa, gdzie posługiwał jako spowiednik. Jesienią 1943 r. został asygnowany do klasztoru św. Józefa w Warszawie. Pracował w wielu klasztorach m.in. w Krakowie, Tarnopolu, Czortkowie, Jarosławiu, Tarnobrzegu, Gidlach, Warszawie. Był cenionym rekolekcjonistą. Zob. APPD, Pp 597/111, O. Ordon Szymon Piotr † 01.08.1962, s. 3, APPD, Kr 842, s. 95-96, 169, 171, 175; Księa zmartych, zapis pod datą 1 sierpnia. W jego teczce osobowej zachowało się zezwolenie od władz GG z datą 5 VII 1941, które pozwalało mu na jednorazowe przemieszczenie się (tam i z powrotem) między Krakowem a Tarnobrzegiem. Zob. APPD, Pp 597/111, O. Ordon Szymon Piotr $\uparrow$ 01.08.1962, s. 17.

${ }^{65}$ Sadok Marian Kolasiński - (ur. 14 IX 1912 w Sandomierzu, zm. 30 X 1991 w Jarosławiu). Profesję zakonną złożył 10 VIII 1936, święcenia kapłańskie otrzymał 24 VI 1941 w Krakowie. Pracował w kilku klasztorach w prowincji. Po II wojnie światowej był zaangażowany w organizację Małego Seminarium w Jarosławiu. Od 1974 r. do końca życia pracował w Jarosławiu, gdzie zajmował się Trzecim Zakonem Św. Dominika. Zob. Księga zmartych braci i ojców Polskiej Prowincji Zakonu Kaznodziejskiego czyli Dominikanów, wyd. IV, Warszawa 2007, s. 131 (cyt. dalej: Księga zmarlych braci i ojców).

${ }^{66}$ Miał on również mszę prymicyjną w pobliskim klasztorze sióstr dominikanek w Wielowsi. Zob. T. Zych, Tarnobrzeg pod okupacją niemiecka, s. 175.

${ }^{67}$ Damian Jakub Budnik - (ur. 22 IX 1910 w Berezowicy Małej k. Zbaraża, zm. 18 XI 1971 w Świętej Annie). Profesję zakonną złożył 20 VIII 1930, a święcenia kapłańskie otrzymał 25 VII 1938. Był przeorem klasztorów w Żółkwi, Lublinie, Gdańsku, Wrocławiu oraz Gidlach. Głosił rekolekcje i misje święte w wielu parafiach w całym kraju. Otrzymał tytuł kaznodziei generalnego. Przez wiele lat sprawował funkcję kapelana sióstr dominikanek w Swiętej Annie. Zob. Księga zmarlych braci i ojców, s. 141.

${ }^{68}$ Ojciec Madura od lipca $1941 \mathrm{r}$. starał się u władz niemieckich o niezbędne pozwolenie na przeprowadzenie koncertu. 7 sierpnia otrzymał odpowiedź, że zgłaszana przez niego inicjatywa nie budzi zastrzeżeń. Został zobowiązany do przedstawienia dokładnego programu wystąpienia, na podstawie którego otrzymał zgodę. Zob. APPD, sygn. Tb 149, [brak paginacji], list z dn. 28 VII 1941, 7 VIII 1941. 
W połowie października bawił przez parę dni w klasztorze o. Łucjan Wołek ${ }^{69}$.

W dzień Wszystkich Świętych o godz. 2-giej popołudniu odbyła się procesja żałobna z kościoła na cmentarz. Zaś o godz. 5-tej w kościele godzina muzyki religijnej w wykonaniu artystów i chóru kościelnego. Dochód z dobrowolnych datków został przeznaczony na kuchnię dla ubogich.

Pasterka w tym roku odbyła się o północy za specjalnym zezwoleniem władz niemieckich ${ }^{70}$.

\section{Rok 1942}

W marcu tego roku od Niedzieli Męki Pańskiej do Palmowej głosił rekolekcje wielkopostne dla parafian o. Józef Burda ${ }^{71} \mathrm{z}$ Lublina.

29 i 30 czerwca odbyła się kanoniczna wizytacja parafii przez J. E. Ks. Biskupa Tomakę ${ }^{72}$ sufragana przemyskiego.

${ }^{69}$ Łucjan Józef Wołek - (ur. 17 VII 1894 w Sielcu k. Dębicy, zm. 1 IV 1968 w Poznaniu). Profesję zakonną złożył 19 III 1916, a święcenia kapłańskie otrzymał 20 III 1920. Głosił liczne rekolekcje oraz misje ludowe. Otrzymał tytuł zakonny kaznodziei generalnego. Ukończył studia z historii na Uniwersytecie Jana Kazimierza we Lwowie, a następnie pracował jako wykładowca w seminarium dominikańskim we Lwowie. Był prefektem w dominikańskim internacie w Żółkwi, a także przeorem w kilku klasztorach, m.in. w Czortkowie, Jarosławiu, Lublinie, Gidlach oraz Borku Starym. Zob. Księga zmartych braci i ojców, s. 49.

${ }^{70}$ Zob. T. Zych, Tarnobrzeg pod okupacją niemiecka, s. 174. Przeor rozpoczął starania u władz niemieckich w Dębicy 12 XII 1941 r. Zob. APPD, sygn. Tb 149, [brak paginacji], dokument z dnia 16 XII 1941 roku.

${ }^{71}$ Józef Kazimierz Burda - (ur. 23 III 1905 w Soworach k. Białej Podlaskiej, zm. 1XI 1978). Profesję zakonną złożył 6 VIII 1931, święcenia kapłańskie otrzymał 29 VI 1936. Pracował w wielu klasztorach, m.in. w Jarosławiu, Gidlach, Gdańsku i Poznaniu. Pełnił urząd przeora w Borku Starym. Był gorliwym kaznodzieją i misjonarzem. Otrzymał tytuł zakonny kaznodziei generalnego. Podczas rekolekcji w listopadzie 1949 r. w warszawskiej parafii św. Michała został za trzymany przez UB i skazany na cztery lata więzienia za wrogie wystąpienie przeciwko władzy, jednak po dwóch został zwolniony. Zob. Ksiegga zmarlych braci i ojców, s. 134; M. Miławicki, Dominikanie w Polsce po II wojnie światowej - stan badań, [w:] Komunistyczny aparat represji wobec Polskiej Prowincji Dominikanów, red. M. Miławicki, M. Wenklar, Kraków 2015, s. 42; M. Miławicki, Dominikański gazda na Wiktorówkach. O. Pawet Kielar i duszpasterstwo tatrzańskie w latach 1958-1967, [w:] tamże, s. 396.

${ }^{72}$ Wojciech Tomaka bp - (ur. 27 II 1875 w Trzebownisku koło Rzeszowa, zm. 6 II 1967 w Przemyślu). Po ukończeniu szkoły średniej w Rzeszowie w 1895 r. wstąpił do Seminarium Duchownego w Przemyślu. Po studiach filozoficzno-teologicznych 8 VI 1899 r. otrzymał święcenia kapłańskie. W 1900 r. rozpoczął studia teologiczne na Gregorianum w Rzymie, a po roku z polecenia bp Pelczara przeniósł się na wydział Prawa Kanonicznego, gdzie 3 VII 1903 r. uzyskał stopień doktora. Po powrocie do został kapelanem biskupa ordynariusza, a także podjął wykłady w miejscowym Instytucie Teologicznym z prawa kanonicznego. Jego działalność obejmowała także katechizowanie w filii Gimnazjum na Zasaniu, w Państwowym Seminarium Nauczycielskim Żeńskim. W latach 1911-1912 był dyrektorem prywatnego żeńskiego Seminarium Nauczycielskiego u ss. Benedyktynek w Przemyślu. Należał do Związku Katolicko-Społecznego, a także angażował się w organizacje młodzieżowe. Jego doświadczenie i zamiłowanie pedagogiczne wpłynęło na powierzenie mu wykładów z pedagogiki i katechetyki w Instytucie Teologicznym w Przemyślu. W latach 1926-1934 należał do sądu biskupiego jako oficjał, gdzie był doradcą w sprawach małżeńskich, natomiast w latach 1942-1945 oraz 1950-1966 był prezesem sądu II instancji. 25 XI 1933 roku papież Pius XI mianował go biskupem pomocniczym diecezji przemyskiej. Święcenia biskupie otrzymał 21 I 1934 r. z rąk bpa Franciszka Bardy. W tym samym roku został mianowany wikariuszem generalnym diecezji. Po rozpoczęciu II wojny światowej - w latach 1939-1941 - zarządzał częścią diecezji, znajdującą się pod okupacją sowiecką. Głównymi dziedzinami działalności bp. Tomaki była Akcja Katolicka, funkcje w kurii biskupiej i wizytacje diecezjalne, które odprawiał z zamiłowaniem i życzliwością ze strony wiernych. Zob. K. Krasowski, Biskupi katoliccy II Rzeczypospolitej. Stownik Biograficzny, Poznań 1996, s. 240-241. 
2-go sierpnia wieczorem w kościele chór kościelny pod kierunkiem o. przeora Fabiana Madury wykonał szereg utworów religijnych między innymi Oratorium Pasyjne ${ }^{73}$. Dobrowolne datki przeznaczono na budowę nowych organów.

Od 2 do 11 lipca przebywał w Tarnobrzegu o. prowincjał Maurycy Majka ${ }^{74}$.

Z końcem sierpnia opuścił Tarnobrzeg o. Kasjan Jagiełło. Na jego miejsce przyjechał w listopadzie ojciec Bronisław Pittner ${ }^{75}$.

8 grudnia w dzień Matki Boskiej Niepokalanego Poczęcia z powodu trudności władz niemieckich uroczysta suma odprawiała się dopiero o 6 godz. wieczorem. Przed południem był obowiązek pracy.

Pasterka w tym roku była dopiero rano w dzień Bożego Narodzenia, a nie jak w roku zeszłym o północy.

W okresie od stycznia 1940 r. do listopada 1942 r. za przeorstwa o. Fabiana Madury przeprowadzono częściowy remont zniszczonego wskutek działań wojennych w roku 1939 dachu kościoła i klasztoru ${ }^{76}$. Część dachu klasztoru pokryto blachą pocynkowaną i żelazną w miejsce dawnego zniszczonego łupku. Gruntownego remontu dachu klasztoru nie można było przeprowadzić z powodu zakazu władz niemieckich, jak również wskutek wojennych ciężkich warunków zdobycia potrzebnego materiału budowlanego. Wstawiono nowe okno w miejsce zniszczonego odłamkami granatu, postawiono 1 piec nowy, a 9 pieców przestawiono. Odmalowano chórek zakonny, 6 cel oraz górny i dolny korytarz wraz ze schodami.

W gospodarstwie kupiono 1 konia, 2 krowy, 1 nowy pług jednoskibowy, 1 nowy parnik, nowe brony, nowe chomąto, maszynkę używaną do krajania buraków, rower damski. Sprawiono nowe koła do wozu. Otoczono parkanem pasiekę. Zasadzono około 200 szczepów owocowych.

${ }^{73}$ Wydarzenie to odbiło się tak szerokim echem w Tarnobrzegu i okolicy, iż władze okupacyjne nie wydały więcej zgodny kolejne wystąpienia publiczne, nawet gdy zwracał się o takie pozwolenie miejscowy oddział RGO. Zob. T. Zych, Tarnobrzeg pod okupacja niemiecka, s. 98.

${ }^{74}$ Maurycy Antoni Majka - (ur. 4 XI 1895 w Sielcu k. Dębicy, zm. 17 XI 1951 w Krakowie). Profesję zakonną złożył 4 X 1914, świecenia kapłańskie otrzymał 20 III 1920. Początkowo pracował jako wikariusz i katecheta w Czortkowie. Został wybrany na syndyka prowincji. W latach 1938-1946 sprawował urząd prowincjała Polskiej Prowincji Zakonu Kaznodziejskiego. Był wykładowcą języka greckiego orazłacińskiego w seminarium dominikańskim. Zob. Księga zmarlych braci i ojców, s. 140; M. Miławicki, Dominikański gazda na Wiktorówkach. O. Pawet Kielar i duszpasterstwo tatrzańskie w latach 1958-1967, s. 340.

${ }^{75}$ Bronisław Pittner - (ur. 2 IX 1911 w Podkamieniu, zm. 12 IX 1979 w Jarosławiu). Profesję zakonną złożył 1 IX 1929, święcenia kapłańskie przyjął 7 III 1937. Pracował w wielu klasztorach, m.in. w Tarnopolu, Lwowie, Tarnobrzegu, Lublinie, Warszawie (na Służewie), Jarosławiu, gdzie poza obowiązkami zakonnymi pracował jako katecheta. Był uzdolniony muzycznie, w związku z czym prowadził chóry w miejscach, gdzie pracował, a także pełnił funkcję organisty na początku lat pięćdziesiątych na Służewie oraz pomagał jaki nieoficjalny wikary w parafii św. Katarzyny. W czasie okupacji był zaangażowany w działalność konspiracyjną. Należał do Armii Krajowej, a także Zrzeszenia Wolność i Niezawisłość. Był mocno zaangażowany w działanie szczególnie tej drugiej organizacji, do tego stopnia, że w okresie okupacji ukrywał w klasztorze jej archiwum. Zob. Księga zmartych braci i ojców, s. 111; W. Szymborski, Ze Lwowa poprzez Włochy, Austrię do odrodzonej Polski, s. 297, 312.

${ }^{76}$ Więcej nt. prac remontowych zob. APPD, sygn. Tb 12, Akta konserwacji kościoła i klasztoru oo. Dominikanów w Tarnobrzegu oraz odbudowa po zniszczeniu światyni przez pierwsza wojnę światowa (1914) z lat 1828-1946. 
Ogród warzywny i sad wydzierżawiano co roku p. Zofii Gronkównej ${ }^{77}$.

Inwentarz kościelny był następujący: 41 ornatów, 8 dalmatyk, 13 kap, 18 alb, 10 pasków, 12 komży dla księży i 28 dla ministrantów, 45 korporałów, 220 puryfikaterzy, 24 palek, 28 humerałów, 2 bursy do chorych, 25 obrusów na ołtarze, 5 nakryć na ołtarze, 2 monstrancje, 1 kustodia (cyborium), 3 puszki, 6 kielichów, 3 relikwiarzy, 1 kadzielnica z łódką, 5 mszałów dominikańskich, 2 mszały rzymskie, 3 mszały żałobne dominikańskie, 1 mszał żałobny rzymski, 1 procesjonarz, kropidło metalowe, 1 welon do monstrancji, 4 welony do puszki, 8 dywanów, 14 ampułek, 5 tacek pod ampułki.

Inwentarz gospodarstwa domowego w roku 1942 był następujący: inwentarz żywy: 3 konie, 6 krów, 2 jałówki, 9 świń, 3 owce, 2 barany, 16 indyków, 8 gęsi, 22 kury, 2 koguty. Inwentarz martwy: 2 wozy z kompletem desek i drabin, 1 wózek wyjazdowy, 2 brony, 2 pługi, kultywator, 2 parniki, 2 maszynki do buraków, siewnik, młocarnia, młynek, sieczkarnia, kierat, sanie wyjazdowe, sanie ciężarowe, walec $\mathrm{z}$ drzewa, 3 beczki do gospodarstwa.

Stan zasiewów w roku 1942 na 1943: obsiano 3 morgi pszenicą, 5,5 morgi żytem, przygotowano pod jęczmień 1,25 morgi, pod owies 4,25, pod ziemniaki 3,5 , pod buraki 1,25 morgi.

\section{Rok 1943}

W styczniu tego roku byli w konwencie tarnobrzeskim następujący ojcowie i bracia:

1/ o. Fabian Madura, przeor

2/ o. Jordan Stano

3/ o. Reginald Jadownicki, proboszcz

4/ o. Anioł Siwek, zakrystian i wikary

5/ o. Bronisław Pittner, wikary

W tym roku rekolekcje dla parafian od 11 kwietnia tj. od Niedzieli Męki Pańskiej do Niedzieli Palmowej udzielał o. Ex. Prow[incjał] Lektor i Kazn[odzieja] Generalny ${ }^{78}$ o. Teofil Szczurecki, który pozostał również na święta wielkanocne w konwencie.

Święto Wniebowstąpienia Pańskiego zniesione przez władze niemieckie obchodzono wieczorem uroczystą sumą o godz. 6:30.

\footnotetext{
${ }^{77}$ Zofia Gronkówna - zaprzyjaźniona z klasztorem. Mieszkała w Dzikowie. Wydzierżawiała ogród warzywny i owocowy od oo. dominikanów. W 1941 r. porozumienie między p. Gronkówną a zakonnikami było takie, że ona będzie zarządzać ogrodem i sadem z ramienia klasztoru, a następnie wpłaci do kasy konwentu 6 tys. zł za sprzedane produkty, natomiast nadwyżka będzie stanowiła jej honorarium za pracę. APPD, sygn. Tb 84, s. 17. W Liber consiliorum conventus Dzikowiensis zachował się wpis, że udzieliła ona tarnobrzeskim dominikanom pożyczki bezprocentowej w wysokości 3 tys. złotych. Pieniądze trafiły do zakonników w czerwcu 1940 r., natomiast zostały oddane w styczniu 1942 r. Zob. tamże, s. 12, 20.

${ }^{78}$ Tytuł Kaznodziei Generalnego otrzymał 15 IX 1942 r.
} 
$\mathrm{Na}$ 40-godzinnym nabożeństwie zaczynającym się zawsze w wigilię Zielonych Świątek, kazania głosił w tym roku o. Isnard Szyper ${ }^{79}$.

\title{
W lipcu na rekolekcjach przebywał w Tarnobrzegu o. Czesław Mende ${ }^{80}$, przeor
}

\begin{abstract}
${ }^{79}$ Isnard Szyper - (ur. 15 V 1910 w Tywoni k. Jarosławia, zm. 9 XI 2003 w Krakowie). Do nowicjatu, mieszczącego się w konwencie Świętej Trójcy w Krakowie, został przyjęty 16 VII 1928 r. Pierwszą profesję zakonną złożył rok różniej, po czym rozpoczął studia filozoficzno-teologiczne, początkowo we Lwowie, a następnie w Warszawie. Śluby wieczyste złożył 22 IX 1934 r. Święcenia prezbiteratu otrzymał 7 III 1937 we Lwowie z rąk abp. Eugeniusza Baziaka. W latach 1937-1939 pracował w konwencie św. Józefa na Służewie. W 1939 r. został przyjęty na Wydział Teologiczny Uniwersytetu Jana Kazimierza we Lwowie, by kontynuować rozpoczęte studia z teologii. Nie trwało to jednak długo, gdyż 26 XI 1939 r. otrzymał asygnatę do klasztoru pw. Świętej Trójcy w Krakowie, gdzie pełnił funkcję syndyka klasztoru oraz wychowawcy braci kleryków, a od II 1945 r. magistra nowicjuszy. W grudniu 1947 r. wraz ze współbraćmi rozpoczął pracę duszpasterską w tworzącej się wspólnocie w Gliwicach, której został przełożonym. Wkładał wiele wysiłku, by w tej formującej się wspólnocie były zachowywane wskazania dotyczące życia zakonnego zawarte w konstytucjach. Ojciec Szyper starał się prowadzić szeroką działalność duszpasterską wśród gliwickich studentów, prowadząc dla nich m.in. konferencje i wykłady. Następnie był asygnowany do Warszawy, gdzie powierzono mu odbudowę konwentu św. Jacka przy ul. Freta, a później do Poznania. Od 1953 do 1969 r. pracował jako misjonarz ludowy oraz rekolekcjonista. W tych latach przebywał głównie w klasztorze krakowskim oraz warszawskim. 29 IX 1953 r. został mianowany wizytatorem w konwencie mniszek dominikanek na Gródku, a 8 XI 1954 r. wizytatorem generalnym w konwencie mniszek dominikanek w Świętej Annie k. Przyrowa. Kolejni przełożeniu doceniali jego zaangażowanie oraz szacunek, jakim się cieszył, i powierzali mu kolejne funkcje, m.in. urząd wizytatora braci konwersów profesów i nowicjuszy w konwencie pw. Świętej Trójcy w Krakowie, a także wizytatora braci studentów. W 1961 r. o. Szyper dołączył do grupy misyjnej, której celem było przede wszystkim kaznodziejstwo, głoszenie misji oraz rekolekcji. W latach 1963-1966 pełnił urząd wikariusza generalnego prowincji, a w latach 1968-1969 wikariusza prowincjała. Od jesieni 1972 r. przebywał w klasztorze krakowskim. Jego praca polegała na głoszeniu rekolekcji, spowiadaniu oraz odwiedzaniu osób chorych i starszych, co też wykonywał z dużym zaangażowaniem i gorliwością. Zob. K. Matyja, Szyper Isnard Piotr (1910-2003), „Słownik Polskich Teologów Katolickich”, Uzupełnienia do tomów 1-9, red. R. Prejs (w przygotowaniu); C. Wichrowicz, Stownik polskich pisarzy dominikańskich, s. 538-539; Księga zmartych, zapis pod datą 9 listopada.

${ }^{80}$ Czesław Mende - (ur. 13 XI 1906 w Reńskiej Wsi pow. Koźle, zm. 1971). Do zakonu kaznodziejskiego wstąpił w Krakowie w 1925 r. Pierwszą profesję złożył 2 X 1926 r., a święcenia kapłańskie otrzymał 21 VI 1931 r. Po święceniach kontynuował studia teologiczne we Lwowie. W latach 1935-1936 pracował jako wikariusz w Jezupolu. Od jesieni 1936 r. był asygnowany do klasztoru Świętej Trójcy w Krakowie. Pełnił urząd subprzeora, syndyka klasztoru, od 1938 spowiednika sióstr dominikanek na Gródku, a od 1939 r. magistra braci konwersów. 4 XII 1939 r. został wybrany przeorem klasztoru krakowskiego. Był także dyrektorem Stowarzyszenia bł. Imeldy. Po zakończeniu wojny opuścił Kraków i został asygnowany do Prudnika na Śląsku, gdzie został przełożonym tamtejszej wspólnoty, a także dziekanem tamtejszego dekanatu. W 1946 r. o. Mende został delegatem duchowieństwa do Powiatowej Rady Narodowej w Prudniku. Ponadto był spowiednikiem sióstr elżbietanek i felicjanek. W1949 r. wystąpił z zakonu i rozpoczął pracę w administraturze apostolskiej Śląska Opolskiego. Zmarł w 1971 r. Zob. Catalogus, Leopoli 1932, s. 12; Catalogus, Leopoli 1933, s. 7; Catalogus, Leopoli 1934, s. 13; Catalogus, Leopoli 1935, s. 26; Catalogus, Leopoli 1936, s. 18; Catalogus, Leopoli 1937, s. 9; Catalogus, Leopoli 1938, s. 9; Catalogus, Cracoviae 1942, s. 1; Catalogus, Cracoviae 1946, s. 19; J. Puciłowski, Portrety imienne i bezimienne. Polscy dominikanie a bezpieka 1945-1989, Kraków 2017, s. 43; M. Sanak, Polscy dominikanie wobec rzeczywistości spoleczno-politycznej w kraju w latach 1945-1956, [w:] Dominikanie o Polsce i Polakach od XIII do XX wieku, red. T. Gałuszka, K. Matyja, Poznań 2020, s. 433.
\end{abstract}


konwentu krakowskiego. W sierpniu zaś o. FeliksBednarski ${ }^{81}$ i o. Ex. Prow[incjał] Teofil Szczurecki.

Pasterka w tym roku odbyła się rano o godz. 6.00 w dzień Bożego Narodzenia.

\section{Rok 1944}

17 marca tego roku przybył do Tarnobrzega o. Leon Podgórni ${ }^{82}$ z Podkamienia, cudownie uchodząc przez śmiercią po napadzie „banderowców” Rusinów na klasztor w Podkamieniu ${ }^{83}$.

${ }^{81}$ Feliks Wojciech Bednarski-(ur. 29 X 1911 w Przedrzymichach Małych, zm. 1 II 2006 w Krakowie). Do Zakonu Kaznodziejskiego wstąpił w 1927 r. po V klasie gimnazjum. Po rocznym nowicjacie złożył profesję zakonną 25 IX 1928. Naukę kontynuował w gimnazjum im. H. Sienkiewicza, gdzie w maju 1935 r. zdał maturę. Święcenia kapłańskie przyjął 29 VI 1936 we Lwowie. W 1937 r. uzyskał na Uniwersytecie Jana Kazimierza magisterium z teologii na podstawie pracy dotyczącej rozwoju dogmatów. We wrześniu tego samego roku wyjechał do Rzymu, gdzie na Angelicum studiował teologię i filozofię. W 1938 r. otrzymał licencjat, a 4 VII 1939 r. uzyskał tytuł doktora. Wrócił do Krakowa, gdzie na UJ nostryfikował dyplom. Po wybuchu wojny wyjechał do Lwowa, gdzie przebywał do 1941 r, a następnie do Żółkwi. We wrześniu 1943 r. wrócił do Krakowa. Zostały mu powierzone zajęcia z klerykami z teologii moralnej i pedagogiki, a także prowadził tajne kursy tomistyczne z prof. Stefanem Swieżawskim. W latach 1945-1949 był naczelnym kapelanem ZHP w archidiecezji krakowskiej. We wrześniu 1954 r. doprowadził do końca rozpoczęty przed wojną przewód habilitacyjny. Od końca lat 40. i w latach 50. prowadził liczne wykłady w seminariach dominikańskich oraz w seminarium lubelskim. W 1956 r. generał zakonu skierował o. Bednarskiego do Rzymu, gdzie został on profesorem teologii moralnej na Angelicum. Pracował tam do 1986 r. W 1959 r. został mu nadany najwyższy tytuł naukowy w zakonie - magisterium św. teologii. 3 X 1961 otrzymał nominacje na Konsultora Papieskiej Komisji Kościołów Wschodnich dla przygotowania Soboru Watykańskiego II. A 4 V 1963 został rzeczoznawcą tegoż Soboru i zaprzysiężonym doradcą Komisji d/s. Seminariów, Studiów i Wychowania Chrześcijańskiego. Był sekretarzem generalnym i współpracownikiem abp. J. Gawliny w Komisji przygotowującej rzymskie obchody millennium chrztu Polski. Spełniał też od 1979 r. zadania głównego postulatora beatyfikacji królowej Jadwigi. Do Polski wrócił w październiku 1993 r. i zamieszkał w Krakowie. 16 VI 1994 otrzymał doktorat honoris causa na Wydziale Filozofii Chrześcijańskiej w ATK. Zob. C. Wichrowicz, Stownik polskich pisarzy dominikańskich, s. 21-40; Księga zmarlych, zapis pod datą 1 lutego.

${ }^{82}$ Leon Andrzej Podgórni - (ur. 19 XII 1892 w Jurkowie koło Limanowej, zm. 2 VII 1953 w Gidlach). Przed wstąpieniem do zakonu służył przez 4 lata w wojsku podczas I wojny światowej. Początkowo w Legionach Polskich, następnie w armii austriackiej a później w wojsku polskim. Do zakonu wstąpił w Krakowie 11 XI 1919 r. Po rocznym nowicjacie złożył pierwszą profesję -11 XI 1920, a święcenia kapłańskie przyjął 2 VIII 1925 r. Studiował filozofię w studium zakonnym we Lwowie, a następnie w Lovanium w Belgii. Pracował w kilku klasztorach m.in. w Jezupolu (1937-1941), Bohorodczanach (1941-1942), Podkamieniu (1942-1944), Tarnobrzegu (1944-1948), Krakowie (1948-1949), Prudniku (1949), Lublinie (1949-1952), Gidlach (1952 do śmierci). Zob. APPD, Pp 597/94, O. Podgórni Leon Andrzej † 02.07.1953, passim; APPD, S29/10, Wspomnienia O. Romualda Kosteckiego pisane w Warszawie w konwencie św. Józefa w latach 1982-1986, zeszyt XI, brak paginacji; Księga zmarlych, zapis pod datą 2 lipca.

${ }^{83} \mathrm{~W}$ teczce osobowej o. Podgórniego zachował się list, napisany do prowincjała 18 III $1944 \mathrm{r}$, w którym opisuje napaść Ukraińców na klasztor, a na koniec dodaje: „Będę teraz w Tarnobrzegu, proszę uprzejmie o asygnatę". Por. APPD, Pp 597/94, O. Podgórni Leon Andrzej † 02.07.1953, s. 45-48. Więcej nt. napadu Ukraińców na klasztor w Podkamieniu zob. J.M. Burda, Klasztor Ojców Dominikanów w Podkamieniu podczas napadu band ukraińskich w marcu 1944 roku, Żółkiew 1944; M. Miławicki, „Byj lacha, de tilky złowysz”. Mord ludności polskiej przez ukraińskich nacjonalistów w Podkamieniu i okolicy w dniach 11-16 marca 1944, [w:] Nie zabijaj. Nacjonalizm i ludobójstwo na Kresach wobec Kościoła, etyki chrześcijańskiej i zasad humanizmu, red. W. Osadczy, A. Kulczycki, Warszawa-Lublin 2019, s. 213-275; J. Burda, Wydarzenia w klasztorze dominikanów w Podkamieniu w latach 1943-1944, wprow. J.A. Spież, „Nasza Przeszłość”, 93 (2000), s. 289-340. 
Rekolekcje wielkopostne w tym roku głosił o. Romuald Kostecki ${ }^{84}$.

W dzień Zielonych Świątek o godz. 10-tej nabożeństwo dla wojska niemieckiego, dla których w kościele pozostawiono wolne ławki.

W czerwcu bawił w konwencie o. Joachim Nowak ${ }^{85} .21$ czerwca przyjechał o. Tadeusz ${ }^{86}[$ Stasica-KM] z asygnatą. W połowie sierpnia przyjechał o. Szymon $\operatorname{Ordo}[\mathrm{n}]$.

W lipcu burza wojenna rozszalała nad Tarnobrzegiem ${ }^{87} .29$ lipca około południa padły pierwsze pociski wzniecając pożary. Ludność w olbrzymiej fali skryła się

${ }^{84}$ Romuald Wojciech Kostecki - (ur. 29 XII 1902 w Sułowie k. Wieliczki, zm. 8 VIII 1991 w Poznaniu). Do zakonu wstąpił w 1917 r. w Krakowie, gdzie odbył nowicjat. Studia odbywał we Lwowie, Krakowie oraz w studium generalnym w Le Saulchoir (Belgia). Swoją edukację zwieńczył obronieniem doktoratu z teologii pt. Rola taski $w$ wychowaniu charakteru (praca była pierwotnie napisana w jęz. francuskim). Następnie 23 VI 1928 r. nostryfikował się na Uniwersytecie Lwowskim. Przebywając w Belgii przyjął święcenia kapłańskie 30 VII 1925 r. W latach 1929-1930 specjalizował się z teologii wchodu na Angelicum w Rzymie. Po powrocie do kraju podjął pracę wykładowcy. Początkowo we Lwowie (1930-1937), następnie w Warszawie (1937-1939, 1948-1950, 1972-1973), Krakowie (1939-1948, 1950-1963, 1967-1971). W latach, gdy prowadził wykłady, jednocześnie pełnił funkcję redaktora dwóch dominikańskich czasopism „Róża Duchowna” oraz „Szkoła Chtystusowa". W 1947 r. otrzymał najwyższy tytuł naukowy w Zakonie Kaznodziejskim - magistra świętej teologii. Został mianowany lektorem prymariuszem i stanął na czele jako rektor powstałego Studium Generalnego. W 1948 r. władze zakonne mianowały Kosteckiego profesorem Angelicum, jednak nie objął tej funkcji. Poza obowiązkami naukowymi pełnił on różne funkcje w klasztorach prowincji, m.in. w latach 1948-1951 był przeorem w Krakowie, w 1950 został wybrany na przedstawiciela prowincji na kapitułę generalną, był również wizytatorem klasztoru w Poznaniu i Świętej Annie (mniszki dominikanki). Był wybitnym rekolekcjonistą, misjonarzem i spowiednikiem, w dużej mierze żeńskich wspólnot zakonnych. Autor wielu publikacji, przyczynków oraz recenzji. Zob. J. Duchniewski, Kostecki Romuald OP, [w:] EK, t. 9, Lublin 2002, kol. 966-967; C. Wichrowicz, Kostecki Romuald Wojciech (1902-1991), [w:] Stownik Polskich Teologów Katolickich, t. 8, s. 299-304.

${ }^{85}$ Joachim Józef Nowak - (ur. 18 VI 1899 w Lubaczowie, zm. 26 IV 1957 w Jarosławiu). W 1922 r. rozpoczął nowicjat w Zakonie Kaznodziejskim w Krakowie, następnie w latach 1924-1930 odbył studia filozoficzno-teologiczne we Lwowie. 2 XII 1926 r. złożył śluby wieczyste, a 23 Vi 1929 r. przyjął święcenia kapłańskie. Pracował jako katecheta w Potoku Złotym (1932-1933) oraz Czortkowie (1933-1934). Od 1934 r. został zamianowany administratorem parafii dominikańskiej we Lwowie. W latach 1935-1939 był redaktorem czasopisma „Róża Duchowna”, równolegle pracował w katolickich organizacjach młodzieżowych. W czasie II wojny światowej był proboszczem we Lwowie, a po 1945 r. pracował m.in. w klasztorach w Warszawie, Borku Starym, Krakowie i Jarosławiu. Zob. S. Brzozecki, Nowak Joachim Józef OP, [w:] EK, t. 14, Lublin 2010, kol. 32; Z. Mazur, Nowak Joachim Józef (1899-1957), [w:] Stownik Polskich Teologów Katolickich, t. 6, s. 556-558; C. Wichrowicz, Stownik polskich pisarzy dominikańskich, s. 347; Księga zmartych, zapis pod datą 26 kwietnia.

${ }^{86}$ Tadeusz Stasica - (ur. 10 II 1909 w Moszczanicy k. Żywca, zm. 7 IX 1966 w Warszawie). Profesję zakonną złożył 18 X 1929, a święcenia kapłańskie otrzymał 22 IX 1929. Studiował w studium zakonnym we Lwowie, a następnie w Rzymie, gdzie specjalizował się z prawa kanonicznego. Po powrocie do kraju, pracował jako wykładowca w studium krakowskim ucząc prawa kanonicznego oraz homiletyki. Pracował jako katecheta w Tarnobrzegu oraz Prudniku. Następnie przebywał w klasztorach w Poznaniu i Warszawie. Był cenionym kaznodzieją i rekolekcjonistą. C. Wichrowicz, Stownik polskich pisarzy dominikańskich, s. 514-515; Księga zmartych, zapis pod datą 7 września.

${ }^{87} 13$ VII 1944 r. Armia Czerwona rozpoczęła tzw. operację lwowsko-sandomierską, kierując wojsko w stronę Wisły. Tarnobrzeg i jego okolica stały się najważniejszymi miejscami walk w końcowej fazie działań wojska sowieckiego. Pod koniec lipca podeszły one pod miasto, które zostało przygotowane przez Niemców do obrony, m.in. przy kościele oo. Dominikanów. Ich plan polegał na utrzymaniu linii Wisły, natomiast Armia Czerwona chciała zdobyć przyczółek po drugiej stronie rzeki. Por. T. Zych, Tarnobrzeg pod okupacją niemiecka, s. 245. 
do klasztoru ${ }^{88}$. Przez 10 dni i nocy trudno było wyjrzeć z ukrycia. Samoloty sowieckie nacierając na uciekających Niemców waliły prawie w klasztor bombami, mniemając, że na wieży kościelnej jest niemieckie obserwatorium wojskowe ${ }^{89}$.

3 sierpnia odłamek granatu strzaskał szkło w cudownym obrazie Matki Boskiej Dzikowskiej ${ }^{90}$ nie naruszając obrazu.

3 sierpnia tuż obok klasztoru od strony północno-wschodniej upadła bomba i swoim podmuchem zniosła dach klasztoru zupełnie i wszystkie okna i drzwi wyrwała wraz z futrynami ${ }^{91}$. Pociski zapalne spadły na szkołę będącą obok klasztoru od strony północno-zachodniej.

Dnia 6 sierpnia w niedzielę w święto Przemienienia Pańskiego raniutko wkroczyła do Tarnobrzega czerwona armia bolszewicka ${ }^{92}$. Teraz zaczęli znowu Niemcy bić na Tarnobrzeg na wojsko sowieckie. Wielkimi masami płynęła przez Tarnobrzeg armia sowiecka, chcąc koniecznie wyprzeć Niemców zza Wisły. Pozycja frontowa w Tarnobrzegu trwała jeszcze dni kilka.

Po odsunięciu linii frontu, ludność Tarnobrzega pomogła w usunięciu gruzów sprzed wejścia do kościoła.

Okres działań wojennych od 29 lipca do 6 sierpnia 1944 - tak pisze w swoim sprawozdaniu z II-ego trzechlecia administracji klasztoru w latach 1942-1945 o. Fabian Madura - był dla całego miasta Tarnobrzega, a w szczególności dla naszego kościoła i klasztoru b[ardzo] ciężki, ponieważ ostrzeliwująca miasto, a specjalnie kościół nasz i klasztor, artyleria sowiecka wyrządziła nam b[ardzo] wielkie szkody. Kościół i klasztor otrzymały ponad 100 pocisków armatnich, a więc granatów, szrapneli i min różnego kalibru do $18 \mathrm{~cm}$ włącznie. Najbardziej uszkodzona została wieża kościelna, okno w prezbiterium nad pomnikiem Juliusza Tarnowskiego ${ }^{93}$, nawa boczna południowa oraz wszystkie okna i witraże. Najgorsze spustoszenie wyrządziła jednak rzucona przez lotnika sowieckiego bomba (lotnicza) dużego kalibru, która dnia 3-go sierpnia [1944] o godz. 18:15 podczas wieczornego nabożeństwa spadła tuż obok klasztoru w odległości 6 metrów od strony wschodniej. I jakkolwiek nie zburzyła klasztoru, to jednak wskutek siły wybuchu zniszczyła wszystkie dachy na kościele, klasztorze i budynkach gospodarczych, wyrwała wszystkie okna i drzwi, tak w kościele, jak i w klasztorze, zwłaszcza od strony

\footnotetext{
${ }^{88}$ Mogło w nim przebywać nawet 1000 osób. Z. Mazur, M. Rudnicka, Dominikanie, s. 155.

${ }^{89}$ Niemcy nie umieścili nic na wieży, ale w okolicy kościoła mieli rozstawione stanowiska artylerii. Zob. ibidem. Decyzją Zarządu Miejskiego w Tarnobrzegu z dn. 31 VII 1941 r. na wieży kościoła parafialnego zarządzanego przez oo. dominikanów ustanowiono punkt obserwacyjny dla Straży Pożarnej. APPD, sygn. Tb 149, [brak paginacji], pismo z dn. 31 VII 1941.

${ }^{90} \mathrm{Na}$ temat obrazu i kultu Matki Boskiej Dzikowskiej zob. A. Wójcik-Łużycki, A. Janas, Piękniejsza niż księżyc, jaśniejsza od gwiazd, Tarnobrzeg 2004; Róża Jerychońska i Jej czciciele, red. A. Bielat, Sandomierz 2015.

${ }^{91}$ Zob. T. Zych, Tarnobrzeg pod okupacja niemiecka, s. 245.

${ }^{92}$ Dzień wcześniej - 5 VI 1944 - Armia Czerwona przystąpiła do ostatecznego ataku na Tarnobrzeg. Wojska sowieckie obeszły główny punkt obrony niemieckiej, który znajdował się na Skalnej Górze, i rozbiły go atakiem od tyłu. Zob. T. Zych, Tarnobrzeg pod okupacją niemiecka, s. 245-246.

${ }^{93}$ Juliusz Tarnowski (ur. 26 XII 1840 w Dzikowie, zm. 20 VI 1863 w bitwie pod Komorowem).
} 
wschodniej i północnej. Wszystkie szyby wypadły z okien, naczynia szklane i porcelanowe $\mathrm{w}$ refektarzu i w kuchni uległy zupełnemu zniszczeniu.

Przez okres tych ośmiu najgorętszych dni przebywało w klasztorze naszym około tysiąc ludzi, którzy kryjąc się na dolnych korytarzach, w piwnicach oraz w podziemiach kościoła szukali tutaj schronienia przed gęsto padającymi na miasto pociskami artylerii sowieckiej. Ufność i gorąca wiara przygnała tutaj tych ludzi i naocznie przekonała ich o cudownej opiece N[ajświętszej] Marii Panny Dzikowskiej. Przez cały okres walki o Tarnobrzeg odbywały się w kościele naszym rano msze św[ięte], a wieczorem różaniec i błogosławieństwo, N[ajświętszym] Sakramentem, za wyjątkiem 4 sierpnia (to jest w I-szy piątek miesiąca i uroczystość św. o. Dominika), kiedy to z powodu silnego ostrzeliwania kościoła przez artylerię sowiecką zmuszeni byliśmy odprawiać msze św[ięte] w podziemiach kościoła. Prócz tego ojcowie nasi codziennie odmawiali z wiernymi różaniec i inne modlitwy w piwnicach i podziemiach klasztoru i kościoła.

Powodem, dla którego artyleria sowiecka tak silnie ostrzeliwała nasz kościół i klasztor, było to, że Niemcy stawiali swoje działa tuż obok naszego kościoła i w ogrodzie klasztornym, i stąd ostrzeliwali pozycje sowieckie, a następnie również dlatego, ponieważ, jak to zeznał pewien pułkownik sowiecki, sowieci widząc taką wysoką wieżę kościelną, sądzili, że na niej znajduje się obserwator niemiecki. To jednak nie była prawda, ponieważ podczas całej tej kampanii ani jeden żołnierz niemiecki nie wszedł do klasztoru, ani na wieżę kościelną. Przeciwnie zaś, po zdobyciu miasta żołnierze sowieccy często wychodzili na wieżę i stamtąd robili różne zdjęcia i pomiary.

Noc z 2 na 3 sierpnia była b[ardzo] przykrą. Niemcy bowiem pod naciskiem silnego ataku sowietów wycofali się z miasta na kilka godzin, wśród gęstej strzelaniny artylerii i karabinów maszynowych, a przede wszystkim sowieckich czołgów. Podczas tej walki mnóstwo ludzi w mieście zostało rannych i kilku zabitych, lżej ranni przychodzili do klasztoru prosząc o pierwszą pomoc i opatrunki.

Bardziej tragicznym był dzień 3 sierpnia, kiedy od pocisków artylerii sowieckiej zapaliła się tuż obok budynków gospodarczych klasztoru drewniana szkoła, która doszczętnie spłonęła i tylko dzięki przeciwnemu wiatrowi i deszczowi, który wówczas zaczął, padać nie zapaliły się nasze budynki gospodarcze.

Również ostatnia noc z 5 na 6 sierpnia była pełna grozy, kiedy na ustępujące ostatecznie wojska niemieckie, sowieci poczęli rzucać bomby, z których kilka spadło do naszego ogrodu.

Po wycofaniu się Niemców do Sandomierza ${ }^{94}$ długo jeszcze miasto nasze było niepokojone przez eskadry samolotów niemieckich, zrzucających bomby na będące $\mathrm{w}$ budowie lub już zbudowane mosty na Wiśle. Przy tym ${ }^{95}$ tak we dnie, jak i w nocy słychać było ciągle wybuchy padających za Wisłą granatów artylerii niemieckiej stojącej w Sandomierzu.

\footnotetext{
${ }^{94}$ Między Tarnobrzegiem a Sandomierzem jest odległość ok. 17 kilometrów.

${ }^{95} \mathrm{~W}$ oryginale: tem.
} 
Po zdobyciu Sandomierza pociski artyleryjskie padały już znacznie dalej od naszego miasta i tylko $\mathrm{z}$ dala obserwowaliśmy wybuchy bomb i ostrzeliwania artylerii przeciwlotniczej.

Kilkumiesięczny pobyt wojsk sowieckich w naszym mieście odbił się b[ardzo] ujemnie na całym naszym mieście oraz na jego mieszkańcach.

Wyrzucano ludzi z ich mieszkań, które zajmowali żołnierze sowieccy, prawie wszystkie płoty i ogrodzenia domów i ogrodów zniszczyli żołdacy sowieccy. W ogrodach owocowych czy warzywnych oraz na polach zasianych oziminą kopali oni rowy i budowali bunkry, stanowiska artylerii przeciwlotniczej, rowy strzeleckie i ziemianki, czyli mieszkania w ziemi dla żołnierzy obsługujących artylerię przeciwlotniczą. Wszystkie owoce i jarzyny zniszczyli, względnie oberwali żołnierze sowieccy, nie mówiąc o kradzieżach krów, świń, kur itp. i nie mówiąc o pijatykach, strzelaninach w mieście i o demoralizacji, jaką szerzyli wśród tutejszych kobiet.

Bogu dzięki wojsko sowieckie nie mieszkało w klasztorze, a nawet odnosiło się do nas poprawnie. Natomiast stojące w ogrodzie klasztornym oddziały artylerii przeciwlotniczej zniszczyły zupełnie ogród, owoce zjedli, jarzyny wykopali, trawę zdeptali, a co najgorsze drewniany płot długości 1,000 metrów zupełnie rozebrali i spalili. Podobnie wielkie szkody zrobili żołnierze sowieccy w polu, należącym do klasztoru na tzw. Miechockim, gdzie stała artyleria przeciwlotnicza sowiecka.

Szkody wyrządzone w kościele były następujące: uszkodzenie zachodniej attyki i nawy bocznej, uszkodzenie płatw, krokwi i łat na dachu, zniszczenie dachówek na dachu kościelnym w $80 \%$, uszkodzenie muru zewnętrznego w prezbiterium oraz gzymsów i kapiteli wewnątrz kościoła, uszkodzenie 5 okien żelaznych, zniszczenie wszystkich (13) witraży oraz szyb w oknach kościoła, uszkodzenie wieży kościelnej na całej wysokości jej, uszkodzenie hełmu wieży, blachy miedzianej i zegara, zniszczenie wszystkich okien i szyb na wieży kościelnej. Kosztorys na poprawę powyższych szkód, opracowany przez rządowego upoważnionego budowniczego p. Tychanowicza Józefa ${ }^{96}$ wynosi 710,290 zł.

Szkody wyrządzone w budynku klasztornym: uszkodzenie murów, sklepień, wyłamanie futryn, ram okiennych, drzwi, płatw, krokwi, całego dachu, wybicie wszystkich szyb. Kosztorys na poprawę powyższych szkód opracowany przez wymienionego wyżej budowniczego wynosi 641,289 zł.

Szkody wyrządzone w gospodarskich, budynkach, stajni, oborze, szopie liczyć można na $132,485 \mathrm{zl}$.

Szkody w płodach i plonach wskutek spalenia zboża w kopach przez wojska niemieckie i przez wykoszenie owsa, łąki, żyta, pszenicy, ziemniaków, owoców w ogrodzie, zabrania 10 g. siana liczy się na 215,400 zł.

\section{Rok 1945}

12 stycznia rozpoczęła się ogólna ofensywa sowiecka, która błyskawicznie posunęła się naprzód. Z chwilą oddalenia się pofrontowych wojsk sowieckich ludność

\footnotetext{
${ }^{96}$ Józef Tychanowicz - nie udało się odnaleźć informacji biograficznych.
} 
miejscowa nieco odetchnęła. Skończyły się bowiem przymusowe kwatery w prywatnych domach dla żołnierzy sowieckich, których niejednokrotnie trzeba było żywić.

1 kwietnia w dzień Zmartwychwstania Pańskiego obchodził w naszym kościele prymicje o. Augustyn Uchański ${ }^{97}$ rodem z Tarnobrzega. Kazanie prymicyjne wygłosił o. Anzelm Jezierski ${ }^{98}$.

13 kwietnia w piątek zmarł w Tarnobrzegu o. Jordan Stano, przeżywszy lat 73 życia, 49 lat profesji i 45 lat pracy kapłańskiej. Był to misjonarz ludowy. Według jego zapisków od roku 1922 do 1939 wygłosił on 58 serii rekolekcji wielkopostnych dla parafii w różnych diecezjach lub młodzieży szkolnej, kleryków czy zakonnic. Ponadto 10 serii misji parafialnych sam lub wspólnie z ojcami o. Piotrem Żaczkiem $^{99}$, o. Maurycym Majką, o. Anzelmem Jezierskim. Również zaprowadził w 5 parafiach Bractwo Różańcowe.

\footnotetext{
${ }^{97}$ Augustyn Uchański - (ur. 10 II 1919 w Tarnobrzegu, zm. 25 VI 1995 w Gdańsku). Do zakonu wstąpił w Krakowie w 1936 r. Pierwszą profesję złożył rok później - 28 VIII 1937 roku. Święcenia kapłańskie przyjął 25 III 1945 r. Przez wiele lat pracował w parafiach przy klasztorze we Wrocławiu oraz Prudniku, a także z dużym zaangażowaniem poświęcał się pracy rekolekcyjno-misyjnej. Pełnił posługę duszpasterską także w, Borku Starym (1968-1971), Warszawie (1971-1975), Jarosławiu (1975-1980), Gidlach (1980-1983), Gdańsku (1984-1995). Zob. APPD, Pp 597/203, O. Uchański Augustyn Aleksander $\% 25.06 .1995$, brak paginacji; Księga zmartych, zapis pod datą 25 czerwca.

${ }_{98}$ Anzelm Jezierski - (ur. 2 I 1910 w Gródku Jagiellońskim koło Lwowa, zm. 14 III 1980 we Wrocławiu). Do zakonu wstąpił w Krakowie w 1936 r. Po odbyciu rocznego nowicjatu złożył pierwszą profesję zakonną 3 X 1927 r., a święcenia kapłańskie przyjął 28 VI 1936 r. Po święceniach pracował w Krakowie, gdzie był archiwistą i bibliotekarzem, jednocześnie kończąc studium z archiwistyki w Państwowym Archiwum w Krakowie. Od 1939 r. był asygnowany do Lwowa. Podjął tam studia na Uniwersytecie Jana Kazimierza, a także był archiwistą i bibliotekarzem konwentu. Zajmował się również III Zakonem św. Dominika. W sierpniu 1942 r. został syndykiem, a 3 IX 1943 przeorem we Lwowie. Od III 1945 r. był przełożonym wspólnoty poznańskiej. W 1950 r. przeszedł do archidiecezji tarnowskiej, następnie wrocławskiej, gdzie w Seminarium Duchownym prowadził zajęcia z dykcji i homiletyki. Był kaznodzieją katedralnym i referentem do spraw apostolstwa kobiet. Pracował jako proboszcz w Białym Kamieniu koło Wałbrzycha. W 1970 r. powrócił do Zakonu i został ponownie obłóczony w habit. 20 IV 1971 powtórnie złożył zakonną profesję czasową, a 21 IV 1974 wieczystą. Pracował w klasztorach w Krakowie, Poznaniu, Wrocławiu i Gidlach, gdzie angażował się z prowadzenie III Zakonu Świętego Dominika. Zob. APPD, Pp 579/151, O. Jezierski Anzelm Leon † 14.03.1980, brak paginacji; APPD, Kr 842, s. 135, 186; Catalogus, Leopoli 1937, s. 10; Catalogus, Leopoli 1938, s. 10; Catalogus, Leopoli 1939, s. 14; Catalogus, Cracoviae 1942, s. 9; Catalogus, Cracoviae 1946, s. 18.

${ }^{99}$ Piotr Rudolf Żaczek - (ur. 16 IX 1865 we wsi Prace na Morawach, zm. 8 II 1947 w Świętej Annie koło Częstochowy). Profesję zakonną złożył 24 IX 1885 r. Następnie studiował w Ołomuńcu i Wiedniu. Święcenia kapłańskie przyjął 25 VII 1889 r. Przełożeni wysłali go do prowincji Galicji i Lodomerii, by kontynuował przeprowadzanie reformy w niej. Został mu powierzony urząd submagistra nowicjuszy, następnie został wyłączony do rady klasztoru, a po roku ustanowiono go subprzeorem konwentu krakowskiego. Szybko nauczył się języka polskiego, dzięki czemu jego praca na rzecz zakonu, ale również duszpasterska, przynosiła dobre owoce. W $1896 \mathrm{r}$. został wybrany przeorem. Funkcję tę pełnił przez cztery kadencje - do stycznia 1907 r. W 1910 r. został wysłany do Petersburga przez generała zakonu o. Cormiera, by tam odrestaurować zakon. Kolejny przełożony - o. Theissling - mianował go wikariuszem generalnym na całą Rosję, a papież Pius X - misjonarzem apostolskim. Po wybuchu I wojny światowej, jako poddany austriacki, musiał opuścić Petersburg i został przeorem klasztoru w Pradze. Powrócił do Polski, gdzie zaczął pracować w Gidlach i jednocześnie był kapelanem sióstr dominikanek w Świętej Annie. Zob. C. Wichrowicz, Stownik polskich pisarzy dominikańskich, s. 611-612; Księga zmarlych, zapis pod datą 8 lutego; K. Matyja, Ideał dominikanina w ujęciu o. Cyryla Markiewicza OP (1875-1964), praca magisterska napisana pod kierunkiem ks. dr. hab. Marcina Godawy, obroniona na WT UPJPII w Krakowie w 2020 roku), s. 17-18.
} 
Od połowy kwietnia 1945 roku asygnowany jest do Tarnobrzega z Lublina o. Teofil Patynek ${ }^{100}$.

W tym roku na uroczystość Bożego Ciała tj. dnia 31 maja procesja z Najśw[iętszym] Sakramentem i z 4 Ewangeliami odbyła się po rynku po raz pierwszy po 60 latach, gdyż przez 60 lat odbywała się do Zamku hr. Tarnowskich idąc ulicą Sandomierską. W rynku prawie wszystkie kamienice żydowskie nie nadawały się do urządzania tamże ołtarzy. W tym roku po Żydach już nie ma śladu ${ }^{101}$, więc procesja swobodnie się w rynku odbyła. Przy ołtarzach chór kościelny pod kierunkiem o. Fabiana Madury tutejszego przeora śpiewał responsoria przy akompaniamencie dętej orkiestry.

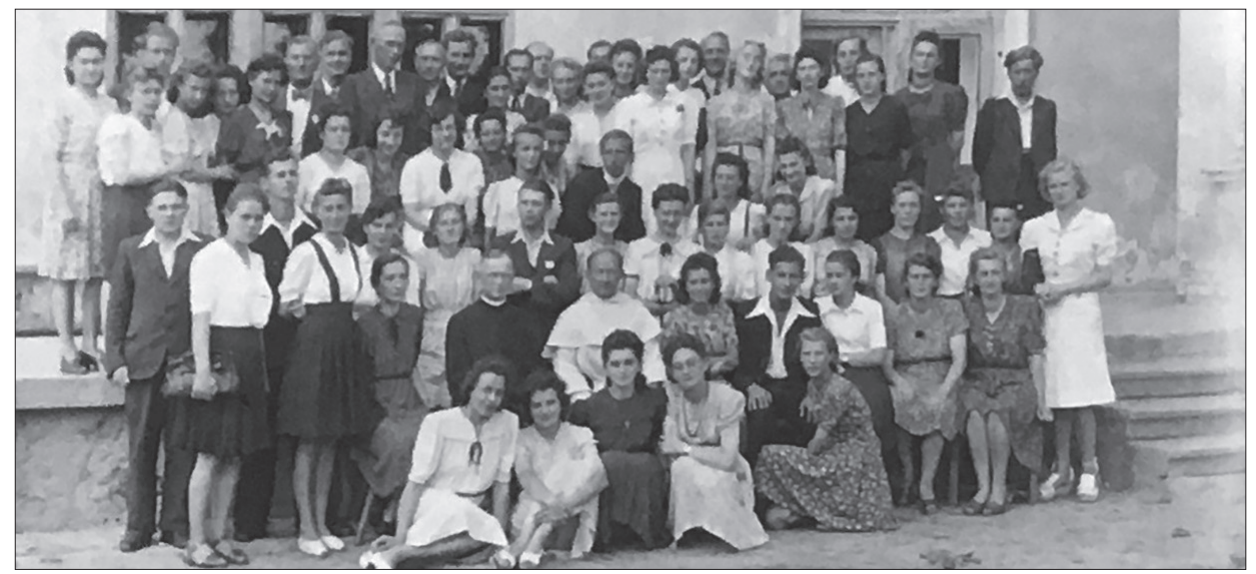

Na zdjęciu oba zespoły chórów katedralnego ze Sandomierza i kościelnego z Tarnobrzega. Dwaj dyrygenci ks. W[endelin] Świerczek ze Zgromadzenia Misjonarzy i o. Fabian Madura.

${ }^{100}$ Teofil Stefan Patynek - (ur. 13 XI 1906 w Dzibułkach, pow. Żółkiew, zm. 20 VIII 1955 w Mierzynie koło Piotrkowa Trybunalskiego). Do zakonu dominikańskiego wstapił w Krakowie w 1925 r. Po odbyciu rocznego nowicjatu 2 X 1926 r. złożył pierwszą profesję zakonną, po czym udał się do Lwowa na studia w tamtejszym studium filozoficzno-teologicznym. Święcenia kapłańskie otrzymał 26 XI 1935 r. Od 1934 r. pracował jako katecheta w Czortkowie, a następnie dostał asygnatę do Podkamienia (1938), gdzie także katechizował oraz prowadził Katolickie Stowarzyszenia Młodzieży Męskiej i Żeńskiej. W 1941 r. otrzymał asygnatę ponownie do Czortkowa, rok później do Podkamienia, jednak dość szybko przełożeni przenieśli go do klasztoru w Bohorodczanach. We wrześniu 1942 r. zamieszkał w Jarosławiu, w czerwcu 1943 r. w Lublinie, z kolei w kwietniu 1945 r. w Tarnobrzegu. Po udzieleniu eksklaustracji w 1946 r. został przyjęty do Administracji Apostolskiej Dolnego Śląska. W latach 1946-1947 był wikariuszem parafii Leszczyniec k. Kamiennej Góry. Po przejściu do diecezji częstochowskiej (1947) pracował jako administrator parafii w Radostowie koło Wielunia. W 1952 r. ostatecznie inkardynowano go do wspomnianej diecezji. Od 1955 r. był administratorem par. w Mierzynie k. Piotrkowa Trybunalskiego. Zob. Catalogus, Leopoli 1936, s. 15; Catalogus, Leopoli 1939, s. 25; Catalogus, Cracoviae 1942, s. 16; M. Sanak, Patynek Teofil Stefan (1906-1955), „Słownik Polskich Teologów Katolickich”, uzupełnienia do tomów 1-9, red. R. Prejs (w przygotowaniu).

${ }^{101}$ Żydzi z Tarnobrzega byli usuwani od października 1939 r. Było to skutkiem ogólnej polityki okupanta wobec tej narodowości, jak powiedział Hans Frank 25 XI 1939 „Z Żydami się nie cackać (...) im więcej umiera, tym lepiej, trafić go - to zwycięstwo naszej Rzeszy". Wypędzani mogli wziąć ze sobą tylko mały bagaż. Stłaczani oni byli w miejscowym getcie. Rozpoczęcie likwidacji getta tarnobrzeskiego rozpoczęło się 19 VII 1942 i było wynikiem decyzji podjętej 20 I 1942 roku na konferencji berlińskiej w Wannesse tzw. ostatecznego rozwiązania kwestii żydowskiej. Osoby zdolne do pracy wywożono do Baranowa Sandomierskiego, gdzie było miejsce zborne dla Żydów z okolicy, a dalej byli transportowani do obozu w Bełżcu. Osoby niezdolne do pracy lub chore zostały rozstrzelane w rejonie Skalnej Góry. Ostateczna zagłada Żydów dokonała się 2 IX 1942. Zob. T. Zych, Tarnobrzeg pod okupacją niemiecka, s. 50, 53, 58-60; A.F. Baran, Szkice z dziejów miasta i jego obywateli, Tarnobrzeg 2012, s. 89-113. 
W dzień święta Chrystusa Króla 21 października po sumie wyruszyła uroczysta procesja na rynek. Wieczorem w Sokole odbyła się religijna akademia ku czci Chrystusa Króla.

W dzień Wszystkich Świętych o godz. 2 popołudniu odbyła się jak co roku żałobna procesja na cmentarz.

2 grudnia o godz. 3 popołudniu w sali kina ${ }^{102}$ odbył się koncert religijny w wykonaniu dwóch chórów, a mianowicie katedralnego z Sandomierza pod kierunkiem ks. W[endelin] Świerczka ${ }^{103}$ ze Zgromadzenia Księży Misjonarzy ${ }^{104}$ i chóru kościelnego z Tarnobrzega pod kierunkiem o. Fabiana Madury.

${ }^{102}$ Kino należało do Towarzystwa Gimnastycznego „Sokół”, które posiadało również salę widowiskową. To w tych miejscach skupiało się życie kulturowe i towarzyskie tarnobrzeżan. Zob. T. Zych, Tarnobrzeg pod okupacja niemiecka, s. 95.

${ }^{103}$ Oryginalny zapis „Świerczyka”.

${ }^{104}$ Wendelin Świerczek CM - (ur. 16 I 1888 w Żytnej koło Rybnika, zm. 12 VIII 1974 w Krakowie). Pierwsze nauki pobierał w miejscowości rodzinnej, a następnie rozpoczął naukę w krakowskim gimnazjum prowadzonym przez księży misjonarzy. Należał do chóru i orkiestry, gdzie grał na skrzypcach i puzonie. Ponadto sam uczył się grać na fisharmonii, a także grał na organach i prowadził chór i orkiestrę w małym seminarium. Do zgromadzenia Księży Misjonarzy został przyjęty 7 IX 1906 w Krakowie na Kleparzu. Będąc na drugim roku studiów prowadził chór dla kleryków oraz pracował jako organista. Wówczas zaczął pisać pierwsze własne kompozycje. W czerwcu $1910 \mathrm{r}$. zdał maturę i rozpoczał czteroletnie studia filozoficzno-teologiczne w stradomskim seminarium w Krakowie. W tym też czasie stworzył orkiestrę mieszaną oraz był dyrygentem chóru. Po otrzymaniu święceń kapłańskich pracował w Nowej Wsi jako nauczyciel, prowadząc zajęcia z fizyki i chemii, a także prowadził chór chłopięcy. Po wybuchu I wojny światowej objął opieką duszpasterską szpital wojskowy w Łobzowie (Szkoła Kadetów). Wiosną 1917 r. został powołany do wojska niemieckiego. Przebywał w Tarnowskich Górach, następnie w Nysie, gdzie pracował w kancelarii szpitalnej. Po zakończeniu działań wojennych wrócił do Nowej Wsi, a po niecałym roku został przeniesiony na Kleparz, gdzie pracował jako kapelan inwalidów wojennych. W styczniu 1921 r. udał się na Góry Śląsk do pracy plebiscytowej w Rybniku. Spośród młodzieży akademickiej i seminarzystów organizował pracowników do szkół powszechnych, przedszkoli i ochronek, gdzie nie było lub brakowało wychowawców i nauczycieli. Prowadził kurs dla dyrygentów i sam kierował chórem. Za tę działalność władze niemieckie próbowały go uwięzić, jednak nigdy to się nie wydarzyło. We wrześniu 1922 r. powrócił do Nowej Wsi, pracował w małym seminarium. W latach 1922-1927 studiował muzykologię na Wydziale Filozoficznym UJ, a także dodatkowo studiował germanistykę oraz pedagogikę. Brał także prywatne lekcje z harmonii. Po skończonych studiach zamieszkał na Stradomiu. Uczył muzyki, prowadził śpiew gregoriański, ale także pracował jako kapelan. W 1930 r. został powołany przez bp. Teodora Kubinę na ojca duchownego w seminarium Częstochowskim. Wówczas też uczył kleryków śpiewu gregoriańskiego. Od jesieni 1936 r. rozpoczął pracę w Wilnie w seminarium i jednocześnie był spowiednikiem ss. bernardynek. Pracował tam tylko dwa lata, bo od 1938 r. był już w Tarnowie. Opiekował się tam łemkowskimi klerykami obrządku bizantyjsko-ukraińskiego, którzy mieszkali w misjonarskim domu. Wybuch II wojny światowej zastał go w Częstochowie. Udało mu się dotrzeć do Tarnowa, skąd często wyjeżdżał w celach duszpasterskich do Nowego Sącza, Jasła i Sanoka. W październiku 1942 r. wyjechał do Sandomierza, gdzie uczył śpiewu w tamtejszym seminarium, a także dyrygował chórem katedralnym. Już po wojnie uczył śpiewu w Państwowym Gimnazjum i Liceum w Sandomierzu. Ponadto był spowiednikiem w seminarium oraz w kilku zgromadzeniach zakonnych żeńskich. Po 25 latach pracy w Sandomierzu w 1968 r. przeniósł się do Krakowa na Kleparz, gdzie 12 VIII 1974 r. zmarł i został pochowany na Cmentarzu Rakowickim. E. Poloczek, Świerczek Wendelin CM, [w:] Stownik biograficzny katolickiego duchowieństwa ślaskiego XIX i XX wieku, red. M. Pater, Katowice 1996, s. 432-433; W. Kałamarz, Ks. Wendelin Świerczek CM - zastużony badacz polskiej pieśni kościelnej, [w:] Recepcja ducha w przestrzeni wiedzy. Sympozjum jubileuszowe 19-20 listopada 2010, red. J. Łucyszyn, S. Rospond, Kraków 2011, s. 193-215; https:// spiewniksiedleckiego.pl/?page_id=173 [dostęp: 23 III 2021]. 
5 grudnia przyjechał do Tarnobrzega 0 . Marek $\mathrm{Kras}^{105}$ na przełożonego w miejsce o. Fabiana Madury, który był przełożonym w Tarnobrzegu przez 6 lat, to jest od roku 1940 do 1945. Przez okres tego przełożeństwa o. Fabian Madura wiele dobrego uczynił dla klasztoru. Rozbudował i ulepszył gospodarstwo, wprowadzając elektryczną instalację do cyrkularki, młocarni, instalację wodociągową w całym budynku klasztornym i budynkach gospodarczych, kanalizację klasztoru, hydrofor, który dostarcza za pomocą prądu wodę do każdej celi, do ogrodu i stajni. W celach wprowadził umywalnie i na piętrze łazienkę, na dole zaś tusz, ustępy odpływowe, w kuchni tzw. boiler na gorącą wodę, która dochodzi do poszczególnych cel. Instalację elektryczną kościoła i klasztoru ulepszył, wprowadzając w miejsce bezpieczników zwanych stopkami powszechnie na automaty, które przy krótkim spięciu nie niszczą się, nie spalają się jak zwykłe stopki tylko wyłączają; po włączeniu ich prąd znowu dochodzi.

O. Fabian Madura swemu następcy to jest o. Markowi Krasowi pozostawił następujący inwentarz:

Inwentarz kościelny: 41 ornatów, 8 dalmatyk, 12 kap, 20 alb, 18 pasków (cingula), 11 komży dla księży, 43 komeżek dla ministrantów, 76 korporałów, 261 puryfikaterzy, 33 palek, 38 humerałów, 2 bursy dla chorych, 38 obrusów ołtarzowych, 10 nakryć na ołtarze, 2 monstrancje, 1 cyborium, 3 puszki, 7 kielichów, 3 relikwiarzy, 5 mszałów dominikańskich, 3 [mszały - dop. KM] żałobne, 4 mszałów rzymskich, 2 umbrakulum, 62 ręczniczki, 3 ręczniki wielkie, 4 sukienek do puszek, 10 dzwonków, 1 żelazko do pieczenia opłatków, 14 dywanów, 2 chodniki do Bożego Grobu, 7 chodników kokosowych.

Inwentarz gospodarski żywy: 2 konie, 5 krów, 1 ciele, 4 świnie, 3 owce, 6 gęsi, 5 kur, 2 koguty. I wiele rzeczy martwego inwentarza jak wozy, sanie, pługi, młocarnia, motor elektryczny wraz z piłą do rżnięcia drzewa.

Ponadto praca społeczna, jak kuchnia dla ubogich ${ }^{106}$, koncerty i chóry, jakie prowadził na terenie Tarnobrzega, pozostawiły miłą pamięć wśród mieszkańców Tarnobrzega i całej okolicy, którzy wspominają tego „dzielnego i sympatycznego lwowianina" i wspominać będą przez długie lata.

Pasterka w tym roku była o północy.

${ }^{105}$ Marek Kras - (ur. 12 IX 1890 w Bryłach koło Jasła, zm. 22 III 1962 w Jarosławiu). Do zakonu wstąpił w Krakowie 27 VII 1907 r. Po odbyciu nowicjatu 28 VII 1908 złożył profesję czasową, natomiast wieczystą 14 IX 1911. Święcenia kapłańskie otrzymał 25 III 1915 r. Od 4 XI 1931 r. był przeorem w Jezupolu. Następnie otrzymał zmianę na przełożonego do Żółkwi, gdzie od 12 XII 1933 był przeorem, a także Dyrektorem III Zakonu św. Dominika oraz promotorem bractwa różańcowego. Od 1934 r. wszedł w skład konsylium prowincji. Kolejnym miejscem pracy był Podkamień. Od 1 VII 1935 pełnił funkcję syndyka konwentu, następnie od 8 XI 1939 przeora, a od 25 I 1942 proboszcza. W 1945 r. otrzymał zmianę do Tarnobrzega. W teczce osobowej zachowała się m.in. asygnata o. Krasa do Tarnobrzega z dn. 15 XI 1945 r. Jednocześnie pełnił urząd proboszcza oraz dyrektora III Zakonu. Następnie pracował w Lublinie (1949-1953) oraz ponownie w Tarnobrzegu (1953-1958) oraz Jarosławiu (1958 - do śmierci). Zob. APPD, Pp 597/110, O. Kras Marek Michat †22.03.1962, s. passim; Ksiega zmarlych, zapis pod datą 22 marca; Catalogus, Leopoli 1932, s. 21; Catalogus, Leopoli 1934, s. 21; Catalogus, Leopoli 1935, s. 23; Catalogus, Leopoli 1939, s. 25; Catalogus, Cracoviae 1942, s. 15; Catalogus, Cracoviae 1946, s. 16.

${ }^{106}$ Por. przypis 27. Ponadto w jednym z dokumentów zachowała się informacja, że oo. dominikanie udostępnili pomieszczenia na kuchnię dla dzieci i młodzieży szkolnej na przełomie 1942/1943. APPD, sygn. Tb 147, [brak paginacji]. 


\section{Bibliografia}

\section{Źródla archiwalne:}

\section{Archiwum Polskiej Prowincji Dominikanów:}

APPD, sygn. Tb 12, Akta konserwacji kościoła i klasztoru oo. Dominikanów w Tarnobrzegu oraz odbudowa po zniszczeniu świąyni przez pierwsza wojnę światowa (1914) z lat 1828-1946.

APPD, sygn. Tb 84, Liber Consiliorum Conventus Dzikoviensis ab A. D. 1938-1949.

APPD, sygn. Tb 100, Notatki dotyczace osób i życia klasztornego OP w Tarnobrzegu, 1828-1945.

APPD, sygn. Tb 122, Sprawozdania budżetowe roczne do Urzędu Prowincjalskiego i kontrybucje na rzecz tegoż Urzędu ze strony Klasztoru OO. Dominikanów w Tarnobrzegu, 1927-1946.

APPD, sygn. Tb 147, Sprawa zniszczeń wojennych kościoła i klasztoru OO. Dominikanów w Tarnobrzegu w latach 1939-1944 i starania o ich odbudowę.

APPD, sygn. Tb 149, Korespondencja Klasztoru OO. Dominikanów w Tarnobrzegu z Władzami Państwowymi, 1939-1945.

APPD, Pp 597/60, O. Twardy Kazimierz Władystaw † 18.12. 1942.

APPD, Pp 597/94, O. Podgórni Leon Andrzej † 02.07.1953.

APPD, Pp 597/111, O. Ordon Szymon Piotr † 01.08.1962.

APPD, Pp 597/110, O. Kras Marek Michat † 22.03. 1962.

APPD, Pp 597/114, O. Siwek Aniot Andrzej † 27.06.1964.

APPD, Pp 579/151, O. Jezierski Anzelm Leon $\uparrow 14.03 .1980$.

APPD, Pp 597/203, O. Uchański Augustyn Aleksander $\uparrow 25.06 .1995$.

APPD, S29/10, Wspomnienia O. Romualda Kosteckiego pisane w Warszawie w konwencie św. Józefa w latach 1982 - 1986

APPD, Kr 842, Kronika Klasztoru krakowskiego OO. Dominikanów przy kościele św. Trójcy od $r$. 1926 do 24 IX 1962 r.

Catalogus fratrum ac sororum Provinciae Poloniae Sacri Ordinis Praedicatorum Anno Domini 1932, Leopoli 1932.

Catalogus fratrum ac sororum Provinciae Poloniae Sacri Ordinis Praedicatorum Anno Domini 1933, Leopoli 1933.

Catalogus fratrum ac sororum Provinciae Poloniae Sacri Ordinis Praedicatorum Anno Domini 1934, Leopoli 1934.

Catalogus fratrum ac sororum Provinciae Poloniae Sacri Ordinis Praedicatorum Anno Domini 1935, Leopoli 1935.

Catalogus fratrum ac sororum Provinciae Poloniae Sacri Ordinis Praedicatorum Anno Domini 1936, Leopoli 1936.

Catalogus fratrum ac sororum Provinciae Poloniae Sacri Ordinis Praedicatorum Anno Domini 1937, Leopoli 1937.

Catalogus fratrum ac sororum Provinciae Poloniae Sacri Ordinis Praedicatorum Anno Domini 1946, Cracoviae 1946.

Catalogus fratrum ac sororum Provinciae Poloniae Sacri Ordinis Praedicatorum Anno Domini 1939, Leopoli 1939.

Catalogus fratrum ac sororum Provinciae Poloniae Sacri Ordinis Praedicatorum Anno Domini 1942, Cracoviae 1942.

Catalogus fratrum ac sororum Provinciae Poloniae Sacri Ordinis Praedicatorum Anno Domini 1946, Cracoviae 1946. 
Biblioteka oo. Dominikanów w Krakowie:

C. Wichrowicz, Stownik polskich pisarzy dominikańskich, Kraków 2009.

K. Matyja, Ideał dominikanina w ujęciu o. Cyryla Markiewicza OP (1875-1964), praca magisterska napisana pod kierunkiem ks. dr. hab. Marcina Godawy, obroniona na WT UPJPII w Krakowie w 2020 r.

Księga zmarłych braci i ojców Polskiej Prowincji Zakonu Kaznodziejskiego czyli Dominikanów, wyd. IV, Warszawa 2007.

Księga zmarlych braci Polskiej Prowincji Zakonu Kaznodziejskiego od 2 lipca tj. od odnowienia Polskiej Prowincji, wydanie do użytku wewnętrznego, Kraków 2020.

\section{Opracowania:}

A.F. Baran, Szkice z dziejów miasta i jego obywateli, Tarnobrzeg 2012.

S. Brzozecki, Nowak Joachim Józef OP, [w:] Encyklopedia Katolicka, t. 14, Lublin 2010, kol. 32.

J.M. Burda, Klasztor Ojców Dominikanów w Podkamieniu podczas napadu band ukraińskich w marcu 1944 roku, Żółkiew 1944.

J. M. Burda, Wydarzenia w klasztorze dominikanów w Podkamieniu w latach 1943-1944, wprow. J.A. Spież, „Nasza Przeszłość”, 93 (2000), s. 289-340.

P. Czepiel, P. Duma, Tarnobrzeg. Kościoły, kaplice, Tarnobrzeg 2015.

J. Duchniewski, Kostecki Romuald OP, [w:] Encyklopedia Katolicka, t. 9, Lublin 2002, kol. 966-967.

A. Janas, A. Wójcik, M. Pietras, Tarnobrzeg. Gród Leliwitów, Tarnobrzeg 1999.

W. Kałamarz, Ks. Wendelin Świerczek CM - zasłużony badacz polskiej pieśni kościelnej, [w:] Recepcja ducha w przestrzeni wiedzy. Sympozjum jubileuszowe 19-20 listopada 2010, red. J. Łucyszyn, S. Rospond, Kraków 2011, s. 193-215.

D. Komada, Obraz Matki Boskiej Dzikowskiej-jego kopie i naśladownictwa, „Rocznik Tarnobrzeski”, 1(1996), s. 88-101.

K. Krasowski, Biskupi katoliccy II Rzeczypospolitej. Słownik Biograficzny, Poznań 1996.

M. Krzysztofiński, Konwent oo. Dominikanów we Lwowie w latach 1939-1943, „Arcana”, 3 (2006), s. $146-164$.

K. Kuśnierz, Rozwój przestrzenny miasta, [w:] Tarnobrzeg. Dzieje miasta 1593-1939, red. F. Kiryk, Tarnobrzeg 2005, s. 534-584.

K. Matyja, Szczurecki Andrzej Teofil (1889-1975), [w:] Stownik Polskich Teologów Katolickich. Uzupetnienia do tomów 1-9, red. R. Prejs (w przygotowaniu).

K. Matyja, Szyper Isnard Piotr (1910-2003), [w:] Stownik Polskich Teologów Katolickich. Uzupetnienia do tomów 1-9, red. R. Prejs (w przygotowaniu).

Z. Mazur, Naleśniak Teodor Jakub (1887-1942), [w:] Słownik Polskich Teologów Katolickich, t. 6, Warszawa 1981, s. 526-529.

Z. Mazur, Nowak Joachim Józef (1899-1957), [w:] Słownik Polskich Teologów Katolickich, t. 6, Warszawa 1981, s. 556-558.

Z. Mazur, M. Rudnicka, Dominikanie, [w:] Diecezja Przemyska w latach 1939-1945, t. III Zakony, red. J. Darus, J. Musiał, Przemyśl 1990, s. 145-175.

M. Miławicki, ,, Byj lacha, de tilky złowysz”. Mord ludności polskiej przez ukraińskich nacjonalistów w Podkamieniu i okolicy $w$ dniach 11-16 marca 1944, [w:] Nie zabijaj. Nacjonalizm i ludobójstwo na Kresach wobec Kościoła, etyki chrześcijańskiej i zasad humanizmu, red. W. Osadczy, A. Kulczycki, Warszawa-Lublin 2019, s. 213-275.

M. Miławicki, Dominikanie w Polsce po II wojnie światowej - stan badań, [w:] Komunistyczny aparat represji wobec Polskiej Prowincji Dominikanów, red. M. Miławicki, M. Wenklar, Kraków 2015, s. 7-43. 
M. Miławicki, Dominikański gazda na Wiktorówkach. O. Paweł Kielar i duszpasterstwo tatrzańskie w latach 1958-1967, [w:] Komunistyczny aparat represji wobec Polskiej Prowincji Dominikanów, red. M. Miławicki, M. Wenklar, Kraków 2015, s. 330-396.

M. Miławicki, Wydarzenia roku 1918 widziane zza klasztornego muru. Kroniki klasztorów dominikańskich jako źródło do badań wydarzeń wojennych, [w:] Rok 1918 w Europie Środkowo-Wschodniej, red. D. Grinberg, J. Snopko, G. Zackiewicz, Białystok 2010, s. 642-659.

E. Poloczek, Świerczek Wendelin CM, [w:] Słownik biograficzny katolickiego duchowieństwa śląskiego XIX i XX wieku, red. M. Pater, Katowice 1996, s. 432-433.

J. Puciłowski, Portrety imienne i bezimienne. Polscy dominikanie a bezpieka 1945-1989, Kraków 2017.

Róża Jerychońska i Jej czciciele, red. A. Bielat, Sandomierz 2015.

M. Sanak, Patynek Teofil Stefan (1906-1955), [w:] Stownik Polskich Teologów Katolickich. Uzupetnienia do tomów 1-9, red. R. Prejs (w przygotowaniu).

M. Sanak, Polscy dominikanie wobec rzeczywistości spoleczno-politycznej w kraju w latach 1945 1956, [w:] Dominikanie o Polsce i Polakach od XIII do XX wieku, red. T. Gałuszka, K. Matyja, Poznań 2020, s. 429-495.

J.A. Spież, Madura Fabian Roman (1982-1989), [w:] Stownik Polskich Teologów Katolickich, t. 8, Warszawa 1995, s. 356-357.

W. Szymborski, Z więzienia w Tarnopolu przez Lwów, Przemyśl i zielona granicę do Tarnobrzega - krytyczna edycja wspomnień dominikanów o. Romana Madury i br. Jacka Matogi z września 1939 r., „Rocznik Przemyski. Historia”, 53 (2017), z. 1(20), s. 289-325.

W. Szymborski, Ze Lwowa poprzez Włochy, Austrię do odrodzonej Polski-sylwetka i dorobek naukowy o. Romana Fabiana Madury, „Res Gestae. Czasopismo Historyczne”, 4 (2017), s. $96-120$.

C. Wichrowicz, Kostecki Romuald Wojciech (1902-1991), [w:] Stownik Polskich Teologów Katolickich, t. 8, s. 299-304.

J. Wołczański, Relacje o stanie kościoła i klasztoru OO. Dominikanów we Lwowie w latach 19391943, [w:] Historia bliższa ludziom. Prace ofiarowane księdzu profesorowi Janowi Kracikowi w 70. rocznicę urodzin, red. E. E. Wróbel, R. Szczurowski, Kraków, 2011, s. $429-448$.

A. Wójcik-Łużycki, A. Janas, Piękniejsza niż księżyc, jaśniejsza od gwiazd, Tarnobrzeg 2004.

A. Wójcik-Łużycki, Tajemnice klasztoru. Z dziejów klasztoru dominikanów w Tarnobrzegu, Tarnobrzeg 2004.

A. Wójcik-Łużycki, Zabytki Tarnobrzega, [w:] Tarnobrzeg. Dzieje miasta 1593-1939, red. F. Kiryk, Tarnobrzeg 2005, s. 608-626.

Zamiatała D., Zrzeszenie Katolików , Caritas” na Pomorzu Zachodnim w latach siedemdziesiatych XX w., [w:] Dzieje Kościoła katolickiego na Pomorzu Zachodnim, t. 3: 1972-1978, red. M. Siedziako, Z. Stanuch, G. Wejman, Szczecin-Warszawa 2018.

A. Zielecki, W dobie autonomii (1867-1918), [w:] Tarnobrzeg. Dzieje miasta 1593-1939, red. F. Kiryk, Tarnobrzeg 2005, s. 179-352.

T. Zych, Tarnobrzeg pod okupacją niemiecka 1939-1944, Tarnobrzeg 2008.

\section{Strony internetowe:}

http://tbc.tarnobrzeg.pl/dlibra/plain-content?id=4485 [dostęp:22 III 2021].

https://spiewniksiedleckiego.pl/?page_id=173 [dostęp: 23 III 2021]. 